Article

\title{
Syntheses of L-Rhamnose-Linked Amino Glycerolipids and Their Cytotoxic Activities against Human Cancer Cells
}

\author{
Makanjuola Ogunsina ${ }^{1}$, Pranati Samadder ${ }^{2}$, Temilolu Idowu ${ }^{1}\left(\mathbb{D}\right.$, Mark Nachtigal ${ }^{2,3,4}$, \\ Frank Schweizer ${ }^{1, *}$ and Gilbert Arthur ${ }^{2, *}$ \\ 1 Department of Chemistry and Biochemistry, Faculty of Science, University of Manitoba, \\ Winnipeg, MB R3T 2N2, Canada; mogunsina@gmail.com (M.O.); idowut@myumanitoba.ca (T.I.) \\ 2 Department of Biochemistry and Medical Genetics, Rady Faculty of Health Sciences, University of Manitoba, \\ Winnipeg, MB R3E 0W9, Canada; sohagdalkutir@gmail.com (P.S.); Mark.Nachtigal@umanitoba.ca (M.N.) \\ 3 Department of Obstetrics, Gynecology and Reproductive Sciences, Rady Faculty of Health Sciences, \\ University of Manitoba, Winnipeg, MB R3E 0W9, Canada \\ 4 Research Institute in Oncology \& Hematology, CancerCare Manitoba, Winnipeg, MB R3E 0V9, Canada \\ * Correspondence: Frank.Schweizer@umanitoba.ca (F.S.); Gilbert.Arthur@umanitoba.ca (G.A.)
}

Received: 4 December 2019; Accepted: 26 January 2020; Published: 28 January 2020

\begin{abstract}
A major impediment to successful cancer treatment is the inability of clinically available drugs to kill drug-resistant cancer cells. We recently identified metabolically stable L-glucosamine-based glycosylated antitumor ether lipids (GAELs) that were cytotoxic to chemotherapy-resistant cancer cells. In the absence of commercially available L-glucosamine, many steps were needed to synthesize the compound and the overall yield was poor. To overcome this limitation, a facile synthetic procedure using commercially available L-sugars including L-rhamnose and L-glucose were developed and the L-GAELs tested for anticancer activity. The most potent analog synthesized, 3-amino-1-O-hexadecyloxy-2R-(O- $\alpha$-L-rhamnopyranosyl)-sn-glycerol 3, demonstrated a potent antitumor effect against human cancer cell lines derived from breast, prostate, and pancreas. The activity observed was superior to that observed with clinical anticancer agents including cisplatin and chlorambucil. Moreover, like other GAELs, 3 induced cell death by a non-membranolytic caspase-independent pathway.
\end{abstract}

Keywords: glycosylated antitumor ether lipids; L-rhamnose-based glycolipids; chemotherapy resistant; caspase independent

\section{Introduction}

Despite increasing investment in cancer research and treatment, the number of new cases and cancer deaths are increasing in both the developed and the developing world, affecting both males and females in nearly the same proportion [1]. Glycosylated antitumor ether lipids (GAELs), a subclass of antitumor ether lipids (AELs) [2,3], are cytotoxic to a wide range of epithelial cancer cell lines grown as adherent and spheroidal cultures as well as cancer stem cells (CSCs) [4-10]. While most anticancer drugs kill cells by inducing apoptosis, GAELs kill cells by an apoptosis independent mechanism $[2,8,9]$, possibly by methuosis [11].

Recently, we reported the synthesis of GAELs with L-glucosamine as the sugar moiety [7]. We showed that in spite of the replacement of D-glucosamine in GAELs with the L-enantiomer, the compounds formed were equally cytotoxic to cancer cells [7]. The rationale for synthesizing the L-glucose analogues of the D-GAELs was to develop compounds that would be resistant to metabolic degradation (especially by glycosidases) as mammals do not have enzymes that metabolise L-glycosidic 
bonds. In the absence of commercially available L-glucosamine, synthesis of the L-glucosamine derived GAELs was initiated with L-mannose and required many synthetic steps. By contrast, L-sugars such as L-rhamnose or L-mannose that are commercially available are relatively simple to attach to a glycerol moiety. Our previous studies have shown that the activity of GAELs depends on the maintenance of a cationic amino group in the molecule [3]. The present study was undertaken to determine whether coupling the L-sugars to the glycerol moiety and maintaining the cationic amino moiety on the glycerol would generate biologically active L-GAELs with activity similar to the previously described L-glucosamine GAEL [7]. The advantage would be facile, cost effective synthetic procedures for potential anticancer compounds. Herein we report the synthesis of a L-rhamnose-GAEL compound and demonstrate its activity against human epithelial cancer cell lines.

\section{Results}

We have recently demonstrated that compound 1, L-glucosamine GAEL (L-Gln) was cytotoxic against human epithelial cancer cells [7]. GAELs with L-sugars other than L-glucosamine (1) were synthesized to assess whether we could produce biologically active GAELs and generate insight on structural features required for activity. Novel L-GAEL analogues, compounds 2-6 (Figure 1), were synthesized and assessed for their cytotoxic activity. The neutral glycoglycerolipid 2 was synthesized to evaluate the effect of replacing L-glucosamine of compound $\mathbf{1}$ and D-glucosamine of $\mathbf{7}$ with the neutral sugar L-rhamnose. Compound 3 was synthesized to evaluate the effect of introducing a cationic moiety into L-rhamnose-based glycoglycerolipid. The primary position of the amine was selected for ease of synthesis. Compound 4 was synthesized to evaluate the effect of amide linkage with $p$-hydroxyphenyl propionic acid. The L-glucose-based cationic compound 5 was synthesized to evaluate the effect of different types of sugars relative to 3 . Compound 6 was synthesized to investigate the effect of the two amino moieties as prior studies showed that additional amino substituent at C-6 position of D-glucosamine-derived GAELs enhanced potency.
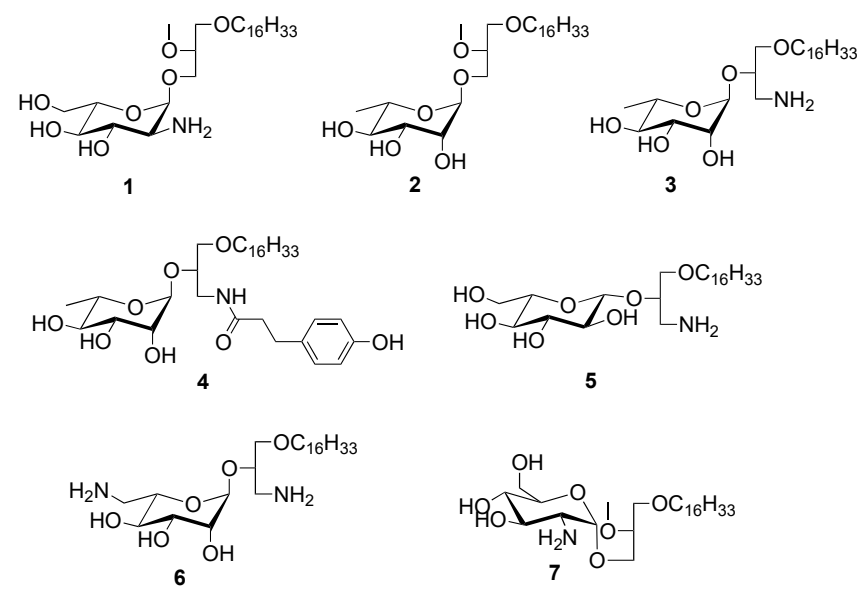

5

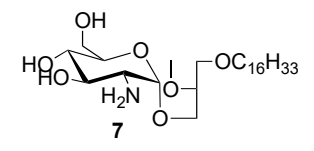

Figure 1. Reference and newly synthesized compounds used in this study. Compound $\mathbf{1}$ is reference L-GAEL, Compounds 2-6 are newly synthesized L-sugar-derived GAELs, and compound $\mathbf{7}$ is reference D-GAEL.

\subsection{Synthesis of L-Sugar Derived Glycolipids 2-6}

The hydroxyl groups of L-rhamnose 8 was protected with acetyl groups using acetic anhydride in pyridine and dimethylaminopyridine as catalyst to give the tetraacetate 9 (Scheme 1). The phenyl thioglycoside 10 was synthesized from 9 by a $\mathrm{BF}_{3} \cdot \mathrm{OEt}_{2}$ promoted glycosylation with thiophenol. Silver triflate promoted glycosylation of $\mathbf{1 0}$ to the commercially available glycerolipid alcohol $\mathbf{1 1}$ yielded the fully protected glycolipid 12. Sodium methoxide-catalysed deblocking of $\mathbf{1 2}$ in methanol gave the desired glycolipid 2 (Scheme 1). 


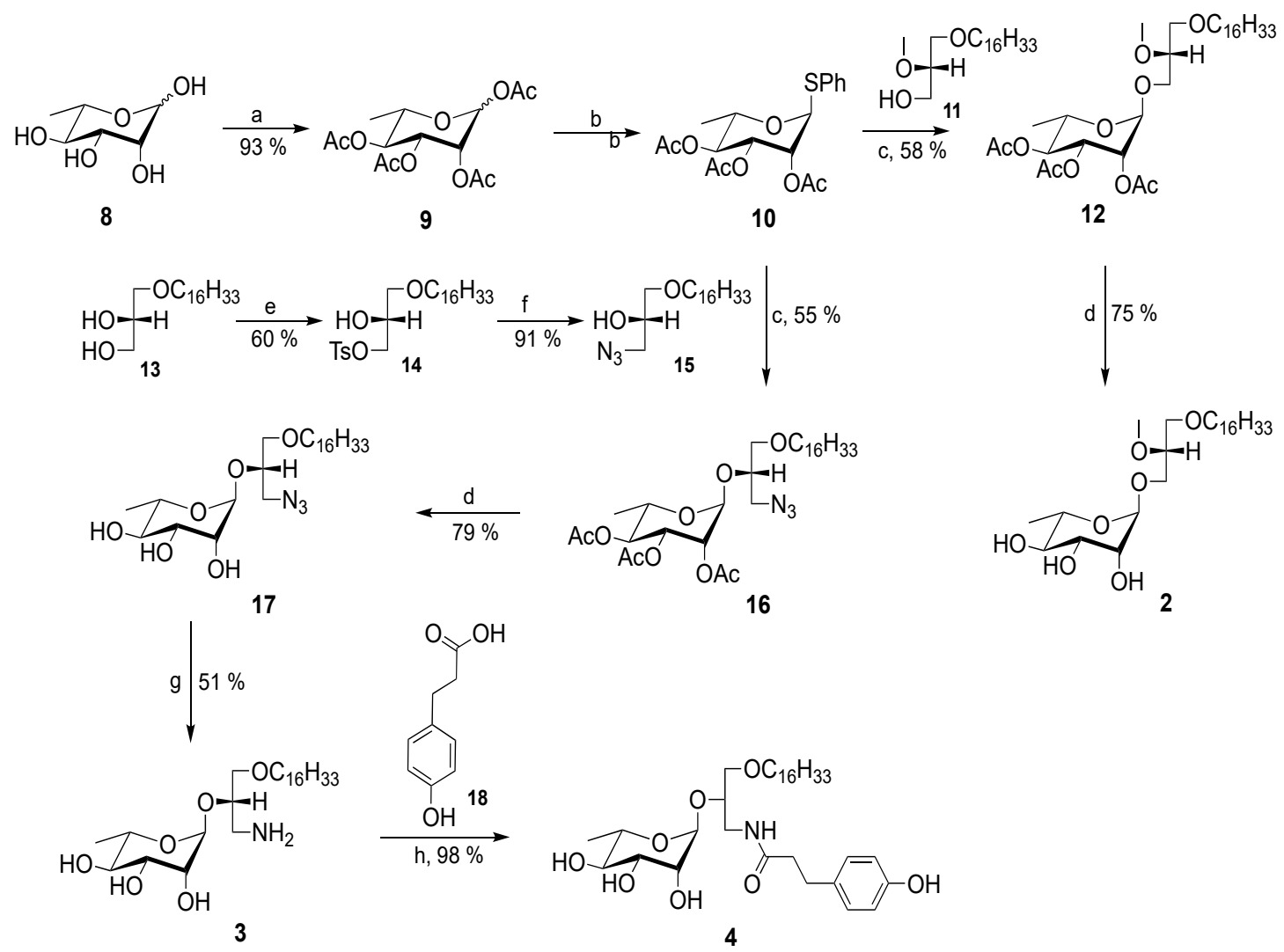

Scheme 1. Synthesis of compounds 2-4. Reagents and conditions: (a) $\mathrm{Ac}_{2} \mathrm{O}, \mathrm{DMAP}, \mathrm{Pyridine}, 18$ h, rt; (b) PhSH, BF 3 Et 2 O, DCM,18 h, rt; (c) AgOTf, NIS, DCM, 3 h, rt; (d) MeONa, MeOH, 1 h; (e) TsCl, Pyridine, DMAP, $0{ }^{\circ} \mathrm{C}$ to rt, 18 h; (f) $\mathrm{DMF}, \mathrm{NaN}_{3}, 70{ }^{\circ} \mathrm{C}$; (g) $\mathrm{P}\left(\mathrm{CH}_{3}\right)_{3}, \mathrm{THF}, \mathrm{H}_{2} \mathrm{O}, 2 \mathrm{~h}, \mathrm{rt}$; (h) TBTU, DMF, 5 h. Abbreviations: 4-dimethyl amino pyridine (DMAP), dichloromethane (DCM), $\mathrm{N}, \mathrm{N}$-dimethylformamide (DMF), room temperature (rt), $\mathrm{N}$-iodosuccinimide (NIS).

Synthesis of compound 3 was achieved by glycosylation of the glycoside donor 10 with the acceptor azido lipid 15, as described above, to give the fully protected azidoglycolipid 16. The azidoglycerolipid 15 was made from the commercially available glycerol-analogue $\mathbf{1 3}$ as previously described [6]. Compound 16 was deacetylated to give the azide 17. Reduction of the azido substituent of 17 was accomplished by using trimethyl phosphine in THF/water mixture to give monoamino compound 3 (Scheme 1). The amide 4 was synthesized by coupling 3 to a pre-activated $p$-hydroxyphenylproprionic acid 18 using TBTU [6] (Scheme 1).

The amino L-glucose based compound 5 was synthesized from L-glucose following the same procedure described above for the synthesis of compound 3 (Scheme 2). 


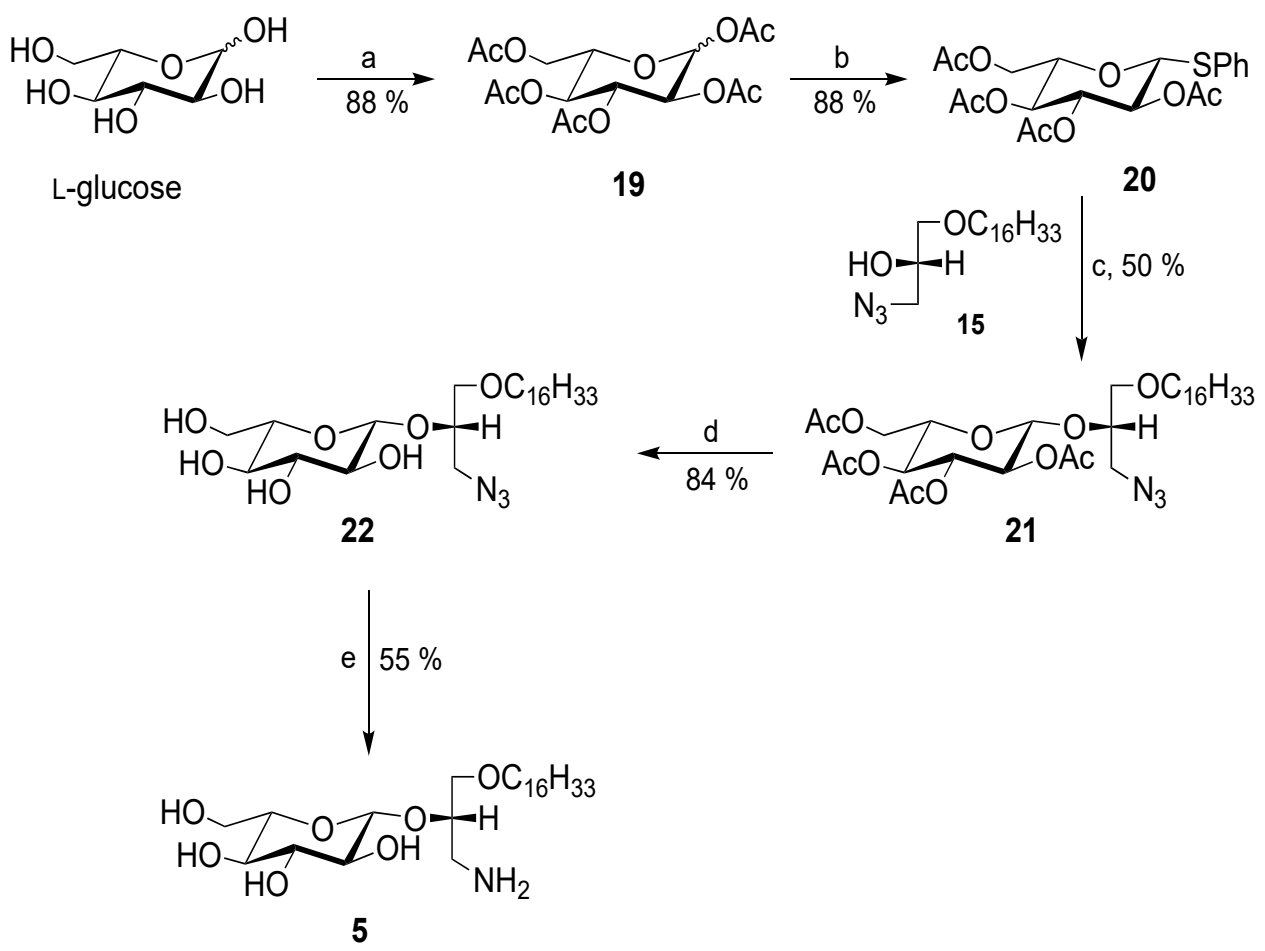

Scheme 2. Synthesis of compound 5. Reagents and conditions: (a) $\mathrm{Ac}_{2} \mathrm{O}, \mathrm{DMAP}$, Pyridine, $18 \mathrm{~h}, \mathrm{rt}$; (b) $\mathrm{PhSH}, \mathrm{BF}_{3} \cdot \mathrm{Et}_{2} \mathrm{O}, \mathrm{DCM}, 18, \mathrm{~h}$, rt; (c) AgOTf, NIS, DCM, 3 h, rt; (d) MeONa, $\mathrm{MeOH}, 1$ h; (e) $\mathrm{P}\left(\mathrm{CH}_{3}\right)_{3}$, THF, $\mathrm{H}_{2} \mathrm{O}, 2 \mathrm{~h}$, rt; (h) TBTU, DMF, argon, 5 h. Abbreviations: 4-dimethyl amino pyridine (DMAP), dichloromethane (DCM), $N, N$-dimethylformamide (DMF), room temperature (rt), $N$-iodosuccinimide (NIS).

Compound 6 was synthesized by coupling of glycoside donor $\mathbf{2 8}$ to lipid alcohol $\mathbf{1 5}$ to afford $\alpha$-glycolipid 29 (Scheme 3). The glycoside donor 28 was synthesized from L-mannose in six steps. At first, the hydroxyl functional groups of L-mannose were acylated to afford pentaacetate 23 as described above. Compound 23 was subsequently converted into thiophenyl glycoside 24 by $\mathrm{BF}_{3} \cdot \mathrm{Et}_{2} \mathrm{O}$ promoted glycosylation with thiophenol. Deacetylation of $\mathbf{2 4}$ gave compound $\mathbf{2 5}$. The azido functional group at the C-6-position was installed by selective activation of the C-6 hydroxyl group in 25 as sulphonate ester to give $\mathbf{2 6}$, followed by nucleophilic displacement of the sulphonate group by sodium azide in DMF to afford the 6-azido analog 27. Protection of the remaining hydroxyl groups using acetic anhydride in pyridine produced the glycoside donor 28. Donor $\mathbf{2 8}$ was used in glycosylation reaction with azido lipid alcohol 15 to produce glycolipid 29. The ester groups were then deprotected to afford the diazido compound $\mathbf{3 0}$ which was subsequently subjected to reduced using trimethyl-phosphine in $\mathrm{THF} /$ water to produce the desired $\alpha$-anomeric glycolipid 6 (Scheme 3). 

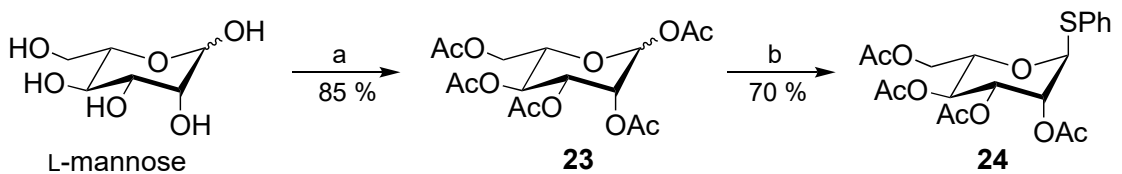

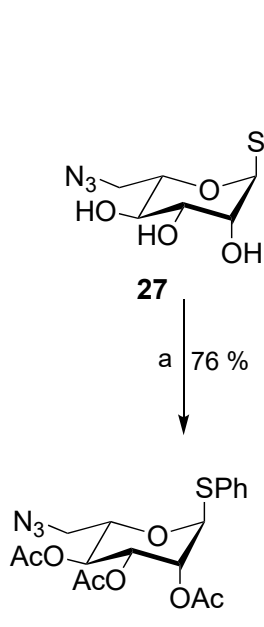

28

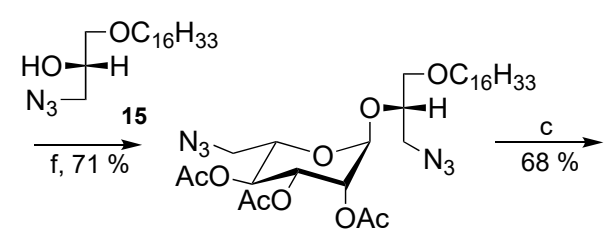

29

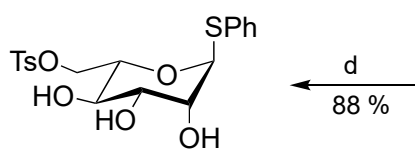

26

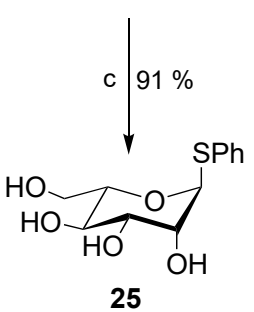

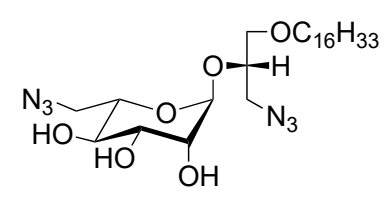

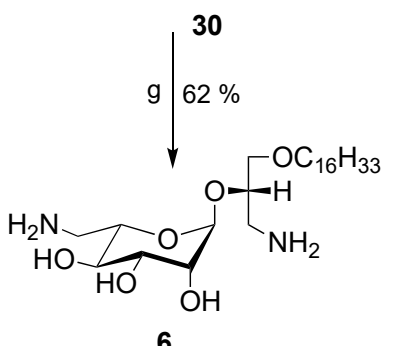

Scheme 3. Synthesis of compound 6. Reagents and conditions: (a) $\mathrm{Ac}_{2} \mathrm{O}, \mathrm{DMAP}$, Pyridine, $18 \mathrm{~h}, \mathrm{rt}$; (b) $\mathrm{PhSH}, \mathrm{BF}_{3} \cdot \mathrm{Et}_{2} \mathrm{O}, \mathrm{DCM}, 18$, h, rt; (c) $\mathrm{MeONa}, \mathrm{MeOH}, 1 \mathrm{~h}$; (d) TsCl, Pyridine, DMAP, $0{ }^{\circ} \mathrm{C}$ to rt, $18 \mathrm{~h}$;

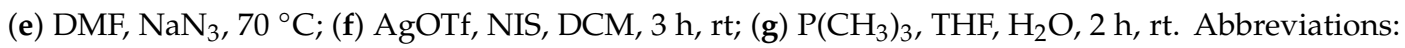
4-dimethyl amino pyridine (DMAP), dichloromethane (DCM), $N, N$-dimethylformamide (DMF), room temperature (rt), $\mathrm{N}$-iodosuccinimide (NIS).

2.2. In Vitro Screening of L-Sugar Derived Glycolipids' Cytotoxic Activity Against Human Epithelial Cancer Cell Lines Derived from Breast, Prostate and Pancreas

The cytotoxic properties of compounds 2-6 were initially determined against exponentially growing human epithelial cancer cell lines including breast (MDA-MB-231, JIMT-1), pancreas (MiaPaCa2) and prostate (DU-145, PC-3) to identify the most active compound. The cells were incubated with increasing concentrations of the compounds $(0-30 \mu \mathrm{M})$ for $48 \mathrm{~h}$ followed by assessment of cell viability using the MTS assay. The most potent of the newly synthesized compounds was the L-rhamno configured glycoglycerolipid 3. This compound carries a primary amino group at the sn-3 position of the glycerolipid and L-rhamno sugar at the $s n-2$ position via an $\alpha$-rhamnosidic linkage. Compound 3 was active with $\mathrm{CC}_{50}$ values of $4.8-14 \mu \mathrm{M}$ (Figure 2 and Table 1). Greater than $90 \%$ loss of cell viability was observed at a concentration range of 7.5-15.0 $\mu \mathrm{M}$ for all the cell lines. Out of these five cell lines, MDA-MB-231, a cisplatin resistant and triple negative breast cancer cell line, was most sensitive to compound 3 . 

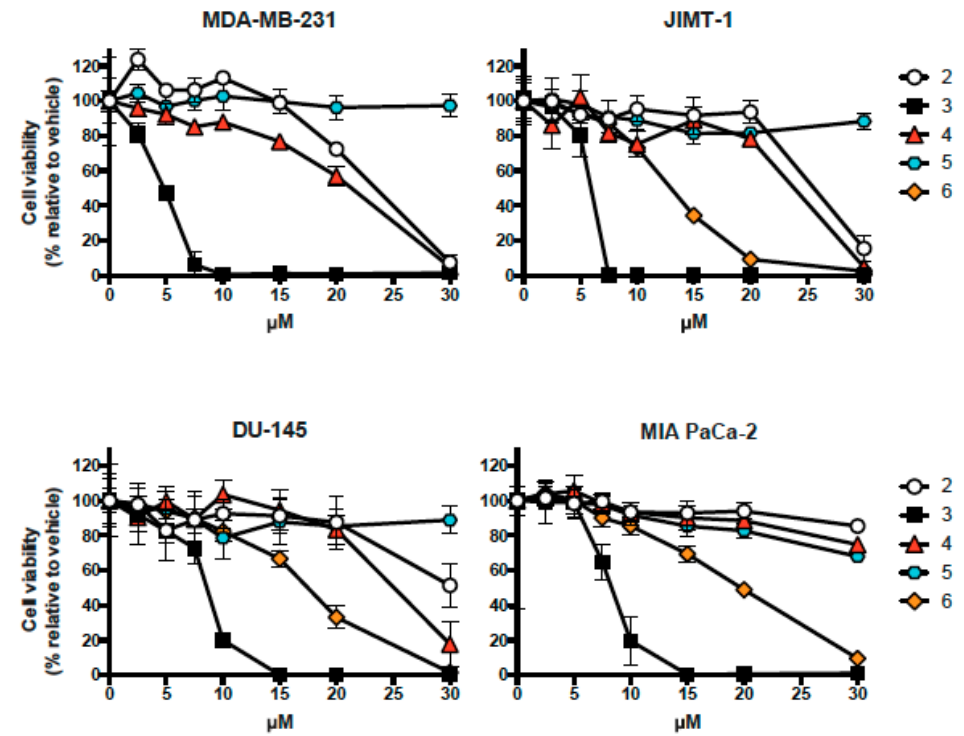

Figure 2. Effects of compounds 2-6 on the viability of MDA-MB-231, JIMT-1, DU-145, and MiaPaCa2 cells lines. Twenty four hours after plating, cells were incubated with compounds 2-6 (0-30 $\mu \mathrm{M})$ for $48 \mathrm{~h}$. Cell viability relative to vehicle control was measured by MTS assay. The results represent the mean \pm standard deviation of 6 independent determinations.

Table 1. $\mathrm{CC}_{50}$ values $(\mu \mathrm{M})$ of chlorambucil, cisplatin, and compounds 1-7 on a panel of human epithelial cancer cell lines: breast (MDA-MB-231, JIMT1), pancreas (MiaPaCa2) and prostrate (DU145, PC3).

\begin{tabular}{cccccc}
\hline & MDA-MB-231 & JIMT-1 & MiaPaCa2 & DU-145 & PC-3 \\
\hline Chlorambucil & $>150$ & $>150$ & $>150$ & $>150$ & $>150$ \\
Cisplatin & $>20$ & NT & $>20$ & 9.2 & NT \\
$\mathbf{1}^{*}$ & 11.0 & 6.5 & 7.5 & 12.5 & 12.5 \\
$\mathbf{2}$ & 26 & 28 & $>30$ & 25 & 25.0 \\
$\mathbf{3}$ & 4.8 & 5.5 & 8.5 & 8.2 & 11.0 \\
$\mathbf{4}$ & 23 & 25 & $>30$ & 30 & 21.5 \\
$\mathbf{5}$ & $\mathrm{NT}$ & $>30$ & $>30$ & $>30$ & $>30$ \\
$\mathbf{6}$ & $\mathrm{NT}$ & 12.5 & 19 & 17.5 & 25 \\
$\mathbf{7}^{*}$ & $\mathrm{NT}$ & 9.0 & 9.0 & 9.0 & 13.5 \\
\hline
\end{tabular}

The $\mathrm{CC}_{50}$ value $(\mu \mathrm{M})$ is defined as the concentration required to decrease cell viability by $50 \%$ relative to the untreated control. NT $=$ not tested. ${ }^{*}$ Results from Ref [7].

The second most potent compound was the L-manno configured bisamine 6 which in contrast to 3 bears a primary amino substituent at the position C-6 of the sugar. This compound was typically $2-$ to 4 -times less active than glycolipid 3 with $\mathrm{CC}_{50}$ values in the range of $12.5-25 \mu \mathrm{M}$ (Table 1 ). This is in contrast to previous observation with L-glucosamine derived GAELs where a primary amino substituent at the C-6 of the L-glucose scaffold enhanced activity [7]. But it is noteworthy that in the D-sugar GAEL series, there was significant loss of activity with mannose analogs [10], $C_{50}$ was not reached at $30 \mu \mathrm{M}$.

The L-rhamnose based analog 2 that is devoid of any amino group and amide 4 were significantly less active than 3 and $\mathbf{6}$ with $C_{50}$ values $\geq 21.5 \mu \mathrm{M}$ across all the five cell lines. The reduced cytotoxicity of compounds 2 and $\mathbf{4}$ when compared to that of compound $\mathbf{3}$ demonstrated that the free amine is an important structural feature required for cytotoxicity of L-sugar-derived GAELs. This is consistent with earlier results on D-glucosamine-derived GAEL series [10]. Surprisingly, compound 5, an analog of 3 where the L-rhamnose is replaced with L-glucose is was less active. Depending on the cell line, loss of viability caused by 5 ranged from $0-35 \%$. We were therefore unable to achieve $\mathrm{CC}_{50}$ at the highest concentration tested $(30 \mu \mathrm{M})$ for any of the cell lines. 
The effects of L-mannose, L-glucose, rhamnose (8) were also tested to determine if these L-sugars displayed any cytotoxicity against the cancer cells. The results revealed that rhamnose, L-mannose and L-glucose were not cytotoxic at the highest dose $(30 \mu \mathrm{M})$ tested (data not shown).

The activity of the most active analogue, L-rhamnose linked glycerolipid 3, was compared with results published on the activity of L- and D-glucosamine based analogs 1 and 7 [7]. Compound 3 is as active or more active $\left(\mathrm{CC}_{50}=4.8-11.0 \mu \mathrm{M}\right)$ than $\mathbf{1}(6.5-12 \mu \mathrm{M})$ or $7(8.0-13.5 \mu \mathrm{M})$ across all the cell lines (Table 1).

The activities of compounds 2-6 against the cancer cell lines were compared with those of clinically-used anticancer agents: chlorambucil and cisplatin. As shown in Table 1, compounds 2-6 were more potent across the five cell lines than chlorambucil. $\mathrm{A} \mathrm{CC}_{50}$ concentration for chlorambucil was not attained even at concentration as high as $150 \mu \mathrm{M}$. Compounds 3 and $\mathbf{6}$ also displayed superior cytotoxicity than cisplatin against all the cell lines. Cisplatin did not achieve $50 \%$ cell death at $20 \mu \mathrm{M}$ against MDA-MB-231 and MiaPaCa-2 cell lines. Thus, the activity of 3 in vitro was better than that of anticancer drugs like chlorambucil and cisplatin. The activity of 3 was similar or better than that of L-glucosamine derived compound $\mathbf{1}$.

Having identified 3 as the most active of the synthesised L-sugar analogues, its effects on the viability of additional cancer cell lines including BT549, MDA-MB-453, MDA-MB-468, and Hs578t (triple negative breast cancer lines), and BT474 (hormone receptor positive breast cancer cells) (Figure 3) was investigated. Concentrations of compound 3 between $6-15 \mu \mathrm{M}$ were sufficient to kill all the triple negative cell lines with the exception of MDA-MB-453 where viability was inhibited by $60 \%$ at the highest concentration tested. $30 \mu \mathrm{M}$ of 3 was required for complete loss of viability of the hormone sensitive breast cancer BT474 cell line.

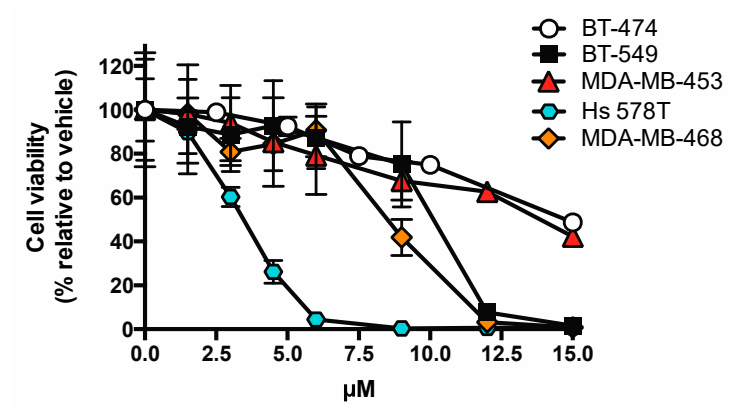

Figure 3. Dose-dependent alteration of cell viability. Human breast adenocarcinoma cell lines were treated with increasing concentrations of 3 . Twenty four hours after plating, cells were incubated with $0-15 \mu \mathrm{M} 3$ for $48 \mathrm{~h}$. Cell viability relative to vehicle control was measured by MTS assay. The results represent the mean \pm standard deviation of 6 independent determinations.

2.3. Determination of the Effect of Pan-caspases Inhibition on Cytotoxicity of Compound 3 in JIMT-1 and DU-145 Cell Lines

One of the hallmark features of cytotoxic GAELs is their ability to kill cancer cells via an apoptosis-independent mechanism [2,4,5,7-9]. We evaluated whether the mechanism of action of 3 was similar to other GAELs. The ability of 3 to kill JIMT-1 and DU-145 cell lines in the presence or absence of QVD-OPh (QVD), an effective pan-caspase inhibitor [12], was investigated. There were no statistically significant differences in cytotoxicity in the absence or presence of $40 \mu \mathrm{M}$ QVD (Figure 4). In contrast, QVD significantly reduced cytotoxicity of Adriamycin, an apoptosis inducing anticancer agent, in JIMT-1 and DU-145 cell lines at all concentration tested. The results of the studies show that compound 3 kills cancer cells via a caspase-independent pathway(s). 

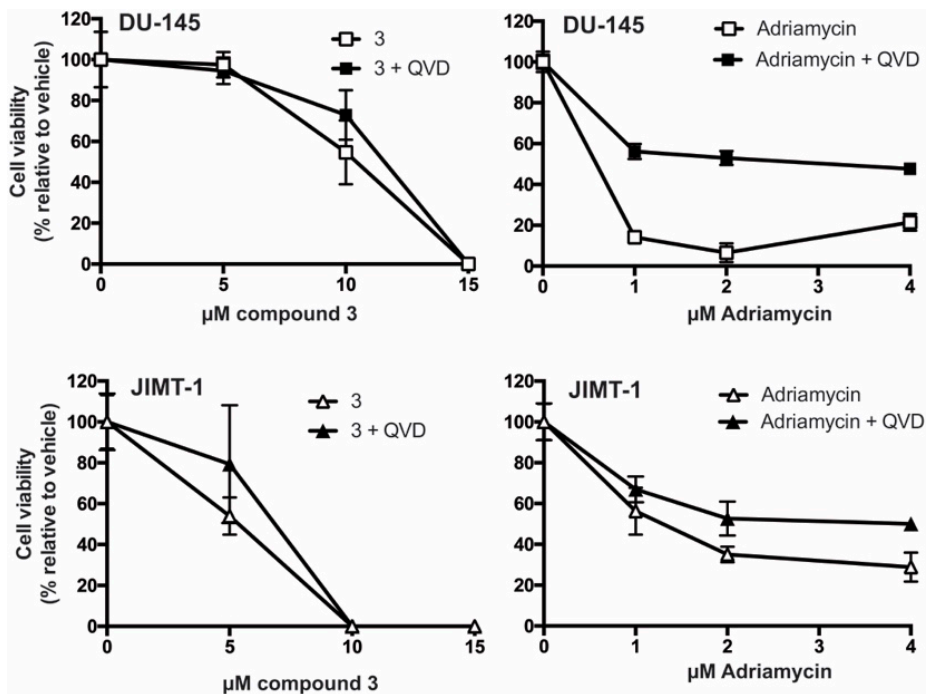

Figure 4. Demonstration of caspase/apoptosis independent cell death. DU-145 or JIMT-1 cell lines were treated with increasing concentrations of 3 or Adriamycin in the presence or absence of $40 \mu \mathrm{M}$ QVD. Four hours after plating, cells were treated with QVD. After $20 \mathrm{~h}$, the cells were incubated with $0-15 \mu \mathrm{M} 3$ or $0-4 \mu \mathrm{M}$ Adriamycin for $48 \mathrm{~h}$. Cell viability relative to vehicle control was measured by MTS assay. The results represent the mean \pm standard deviation of 6 independent determinations.

\subsection{Evaluation of Effect of L-Rhamnose Based GAEL 3 on Integrity of DU145 or JIMT-1 Cell Membranes}

After determining that the mechanism of cell death of compound 3 is independent of caspases-mediated apoptosis, we evaluated if cell death was due to membrane disruption or lysis using the cell impermeant ethidium homodimer-1 (EthD-1) dye that emits red fluorescence upon binding to DNA [13,14]. DU-145 and JIMT-1 were treated with compound 3 at 10 and $15 \mu \mathrm{M}$, respectively. After 4-6 h, the cells were treated with EthD-1 dye and monitored under fluorescence microscopy. Comparison of untreated control cells and cells treated with compound 3 in both DU-145 and JIMT-1 cell lines demonstrated that there was no significant cell membrane lysis. In contrast, cells incubated with $0.01 \%$ Triton X-100 for 10 min stained bright red (Figure 5).

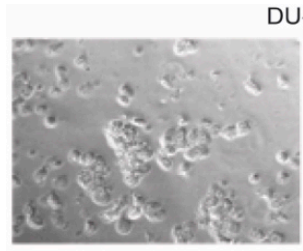

Triton-X-100

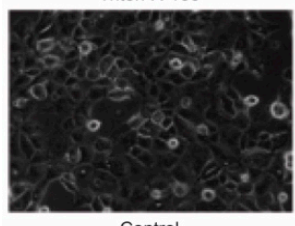

Control

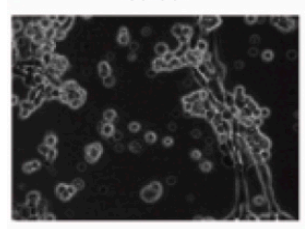

$10 \mu \mathrm{M} 3$
-145

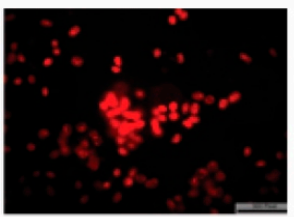

Triton-X-100 stained nuclei

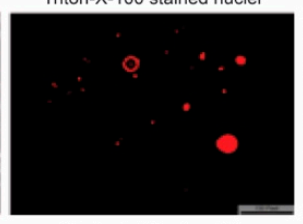

Control stained nuclei

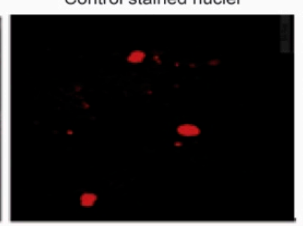

$10 \mu \mathrm{M} 3$ stained nuclei

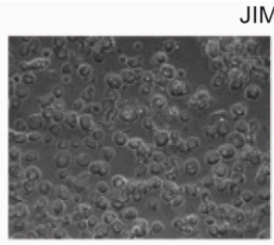

Triton-X-100

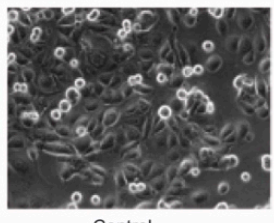

Control

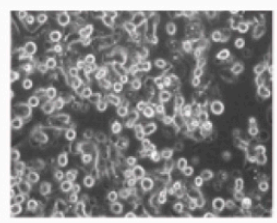

$10 \mu \mathrm{M} 3$
JIMT-1

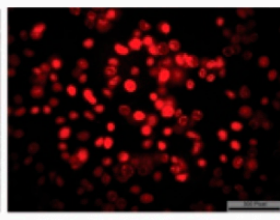

Triton-X-100 stained nuclei

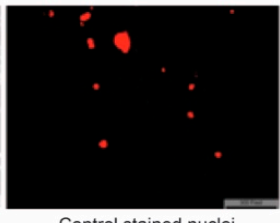

Control stained nuclei

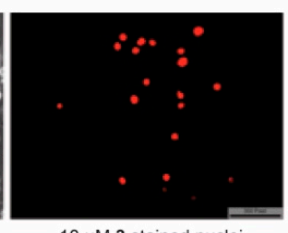

$10 \mu \mathrm{M} 3$ stained nuclei

Figure 5. Evaluation of effect of compound 3 on cell membrane of DU-145 and JIMT- 1 cell lines using cell impermeant ethidium homodimer-1 (EthD-1) dye that emits red fluorescence upon binding to DNA. 


\subsection{Hemolytic Properties of L-Rhamno Configured GAEL 3}

To further evaluate the membrane lytic properties of compound 3, we investigated its capacity to lyse ovine erythrocytes [13]. The highest hemolysis observed with compound 3 was about $6.6 \%$ at $100 \mu \mathrm{M}$ compared to the $1 \%$ ammonium hydroxide positive control (Figure 6). These results indicated that compound $\mathbf{3}$ is not lytic and may be compatible with intravenous administration without concern for hemolysis.

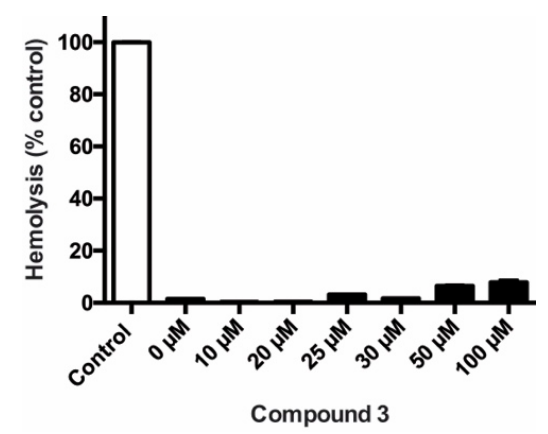

Figure 6. Hemolytic properties of GAEL 3 using freshly isolated ovine erythrocytes. $1 \%$ ammonium hydroxide was used for $100 \%$ hemolysis, the control. The values were determined as $\%$ of control.

\section{Discussion}

GAELs are a promising class of investigational anticancer agents with potent antitumor activity against a range of cancer cell lines and CSCs $[2,3,5,6]$. The biologically active GAELs that we have developed thus far typically have a glycerol backbone with a methoxy group at the C-2 position, a D- or L-glucose at the C-3 position, and an amino group attached to the sugar $[3,4,6,7]$. Due to the relative expense and complexity in synthesizing L-glucosamine GAEL analogues, the objective of the present study was to develop biologically active GAELs with L-sugars via a facile approach that would facilitate large scale synthesis of compounds for in vivo studies. Our previous studies identified that the presence of a primary amine in the molecule is essential for good cytotoxic activity. To simplify synthesis, the amino group was placed at the C-3 position of the glycerol backbone while the L-sugar was placed at the C-2 position. It was reasoned that this would satisfy the requirement for a free amine needed for activity. This was tested with the synthesis of L-rhamnose GAEL (3) and L-glucose-GAEL (5). The results showed that this GAEL scaffold did in fact result in bioactive compounds. Comparison of the activity of the novel compounds synthesised (2-6) against epithelial cancer cell lines derived from breast, pancreas and prostate tumors, revealed that the most potent analog was the L-rhamnose configured analog 3 . The L-rhamnose based analog 2 , which does not have a primary amine, or compound 4 with an amide linkage, were significantly less potent than 3 with a primary amino substituent and L-rhamnose at position $s n-3$ and $s n-2$ of the glycerolipid, respectively. This observation shows that the primary amino substituent is essential for cytotoxicity of this series of GAELs and is akin to what was observed with glucose-based GAELs which required an amino group on the sugar $[2,6,10]$. However, compound 5, an analog in which the L-rhamnose of 3 was replaced with L-glucose showed minimal cytotoxicity. Indeed, $\mathrm{CC}_{50}$ values were not attained at the highest tested concentration for all the cell lines. Thus, the nature and type of sugar moiety in GAELs play a crucial role in their cytotoxicity. We have previously demonstrated with the GAEL series that the nature of the sugar also affects activity [10].

Compound 3 was active against a wide range of breast cancer cells differing in hormone receptor status suggesting that the presence or absence of the receptors was not a determinant in the susceptibility of the cells to compound 3. Thus, BT-474 hormone receptor (HER/2, ER, PR) positive cells and the MDA-MB-453, a TNBC cell line, had similar CC $_{50}$ 's of $14 \mu \mathrm{M}$ vs. $13.8 \mu \mathrm{M}$. Also, JIMT-1 cell line (overexpression of Her2) was more sensitive to compound 3 than some TNBC cell lines. 
Studies conducted to provide insight on the mode of cell death induced by 3 revealed that death occurs via an apoptosis-independent pathway. Thus, the mechanism of action of 3 may be similar to that described for glucose-based GAELs [4,7-9,11]. This non-apoptotic mechanism of cell death may explain why GAELs are effective against resistant cancer lines as cells escape cell death through many mechanisms including over expression of proteins that inhibit caspases and apoptosis [15-17]. Also, the result of membrane disruption experiment using cell impermeant EthD-1 dye demonstrated that 3 does not kill cells by membrane disruption. The fact that the cells were rounding up as they were dying may imply possible interference with the cell cytoskeleton. Our hemolysis assay on ovine erythrocytes further confirmed that L-sugar GAELs induced cell death is not due to interference with cell membrane integrity. The results also indicate that L-rhamnose GAEL 3 may be safely delivered by intravenous administration.

In conclusion, this study identified a novel scaffold for active L-GAELs. The most active compound was L-rhamnose GAEL 3 that has potent cytotoxicity against a spectrum of cancer cell lines. The ease of synthesis makes 3 a suitable compound for large scale synthesis for preclinical studies in rodent models of human cancer.

\section{Materials and Methods}

\subsection{Synthesis of GAELs}

Solvents were dried over $\mathrm{CaH}_{2} \cdot{ }^{1} \mathrm{H}-,{ }^{13} \mathrm{C}-\mathrm{NMR}$ spectra were recorded on an Avance $300 \mathrm{NMR}$ spectrometer (Bruker, Rheinstetten, Germany), and chemical shifts reported (in ppm) relative to internal $\mathrm{Me}_{4} \mathrm{Si}(\delta=0.0)$ and at $75 \mathrm{MHz}$, respectively. NMR spectra $\left({ }^{1} \mathrm{H}-\mathrm{NMR},{ }^{13} \mathrm{C}-\mathrm{NMR}\right)$ of compounds 2-6 are provided in the Supplementary Materials. Thin-layer chromatography (TLC) was carried out on aluminum or glass-backed silica gel GF plates (250 $\mu \mathrm{m}$ thickness) and plates were visualized by charring with $5 \% \mathrm{H}_{2} \mathrm{SO}_{4}$ in $\mathrm{MeOH}$ and or short wavelength UV light. Compounds were purified by flash chromatography on silica gel 60 (230-400 ASTM mesh). ESI-MS analyses were performed on a 500 MS Ion Trap Mass Spectrometer (Varian, Walnut Creek, CA, USA). MALDI-TOF-MS were performed on a Bruker Daltonics Ultraflex MALDI TOF/TOF Mass Spectrometer (Bremen, Germany). Purity of compound 2-6 was assessed by ${ }^{1} \mathrm{H}-\mathrm{NMR}$ spectroscopy after reverse phase chromatography.

\section{1,2,3,4-L-Rhamnopyranosyl Tetraacetate (9)}

L-Rhamnose 8 ( $0.99 \mathrm{~g}, 5.49 \mathrm{mmol})$ was dissolved in $20.0 \mathrm{~mL}$ pyridine at room temperature, then acetic anhydride $(5.20 \mathrm{~mL}, 54.90 \mathrm{mmol})$ and dimethyl amino pyridine $(0.10 \mathrm{~g})$ were sequentially added and the reaction was vigorously stirred for $18 \mathrm{~h}$ after which it was stopped by addition of methanol $(10.0 \mathrm{~mL})$ and then stirred for $15 \mathrm{~min}$. The solvents were removed under high vac. The resulting residue was then dissolved in ethyl acetate $(50.0 \mathrm{~mL}$ ) and washed with $3 \% \mathrm{HCl}$ solution (1 time), saturated sodium bicarbonate ( 2 times), distilled water ( 1 time) and brine (1 time). The resulting organic layer was dried over $\mathrm{Na}_{2} \mathrm{SO}_{4}$ and concentrated to dryness and purified by flash chromatography using ethyl acetate and hexane (1:1) to give $9(1.71 \mathrm{~g}, 5.12 \mathrm{mmol})$ as $\alpha, \beta$ mixture $(9: 1)$. Yield was $93 \%$. NMR data for $\alpha$ - anomer of compound 9: ${ }^{1} \mathrm{H}-\mathrm{NMR}(300 \mathrm{MHz}$, chloroform- $d) \delta 6.01(\mathrm{~d}, J=1.8 \mathrm{~Hz}, 1 \mathrm{H}, \mathrm{H}-1), 5.31$ $(\mathrm{dd}, J=10.1,3.5 \mathrm{~Hz}, 1 \mathrm{H}, \mathrm{H}-3), 5.25$ (dd, $J=3.5,1.8 \mathrm{~Hz}, 1 \mathrm{H}, \mathrm{H}-2), 5.12(\mathrm{dd}, J=10.1,9.9 \mathrm{~Hz}, 1 \mathrm{H}, \mathrm{H}-4)$, $3.93(\mathrm{~m}, 1 \mathrm{H}), 2.17(\mathrm{~s}, 3 \mathrm{H}), 2.16(\mathrm{~s}, 3 \mathrm{H}), 2.06(\mathrm{~s}, 3 \mathrm{H}), 2.00(\mathrm{~s}, 3 \mathrm{H}), 1.24(\mathrm{~d}, J=6.2 \mathrm{~Hz}, 3 \mathrm{H}, \mathrm{H}-6) .{ }^{13} \mathrm{C}-\mathrm{NMR}$ $\left(75 \mathrm{MHz}, \mathrm{CDCl}_{3}\right) \delta$ 170.05, 169.81, 169.79, 168.35, 90.65, 70.48, 68.77, 68.72, 68.65, 20.89, 20.77, 20.74, 20.67, 17.44. ES-MS: calculated (calcd): $\mathrm{C}_{14} \mathrm{H}_{20} \mathrm{O}_{9} \mathrm{Na}^{+} \mathrm{m} / z: 355.1$, found $[\mathrm{M}+\mathrm{Na}]^{+} \mathrm{m} / z: 355.5$.

Phenyl-2,3,4-triacetyl-1-thio- $\alpha$-L-rhamnopyranoside (10)

The tetraacetate $9(1.71 \mathrm{~g}, 5.12 \mathrm{mmol})$ was dissolved in in $20.0 \mathrm{~mL} \mathrm{DCM}$, then thiophenol $(0.68 \mathrm{~g}$, $6.14 \mathrm{mmol})$ and $\mathrm{BF}_{3} \cdot \mathrm{Et}_{2} \mathrm{O}(0.87 \mathrm{~g}, 6.14 \mathrm{mmol})$ were sequentially added. The reaction was stirred vigorously for $18 \mathrm{~h}$ after which it was stopped with $20 \mathrm{~mL}$ saturated sodium bicarbonate at $0{ }^{\circ} \mathrm{C}$. The organic layer was separated using separatory funnel and subsequently washed with saturated $20.0 \mathrm{~mL}$ of sodium bicarbonate ( 2 times), $20.0 \mathrm{~mL}$ of water (1 time) and $20.0 \mathrm{~mL}$ of brine (1 time). 
The organic layer was dried over anhydrous sodium bicarbonate and then concentrated under vacuum. The residue was then purified by flash chromatography using ethyl acetate and hexane (4:6) to give mainly $\alpha$-anomer of $\mathbf{1 0}(1.72 \mathrm{~g}, 4.5 \mathrm{mmol})$. Yield was 88\%. NMR data for the anomer of compound $\mathbf{1 0}$ : ${ }^{1} \mathrm{H}-\mathrm{NMR}$ (300 MHz, chloroform-d) $\delta 7.59-7.22$ (m, 5H, aromatic protons), 5.51 (dd, J = 3.4, 1.1 Hz, 1H, H-2), 5.42 (d, J = 1.1 Hz, 1H, H-1), 5.30 (dd, J = 10.0, 3.4 Hz 1H, H-3), 5.19 (dd, J = 9.6, 10.0 Hz, 1H, H-4), 4.42-4.34 (m, 1H, H-5), 2.15 (s, 3H), 2.09 (s, 3H), 2.05 (s, 3H), 1.26 (d, J = 6.2 Hz, 3H, H-6). ${ }^{13} \mathrm{C}-\mathrm{NMR}$ $\left(75 \mathrm{MHz}, \mathrm{CDCl}_{3}\right) \delta 169.99,169.98,169.91,132.08,131.85,129.19,127.89,85.71,71.34,71.17,69.40,67.79$, 20.91, 20.82, 20.69, 17.35. ES-MS: calcd: $\mathrm{C}_{18} \mathrm{H}_{22} \mathrm{O}_{7} \mathrm{SNa}^{+} m / z: 405.1$, found $[\mathrm{M}+\mathrm{Na}]^{+} m / z: 405.3$.

1-Hexadecyloxyl-2R-methoxyl-3-(2'3'4'-triacetyl- $\alpha$-L-rhamnopyranosyl)-sn-glycerol (12)

The fully protected glycoside donor $10(153 \mathrm{mg}, 0.4 \mathrm{mmol})$ and the glycoside acceptor $11(140 \mathrm{mg}$, $0.4 \mathrm{mmol})$ were dissolved in $15 \mathrm{~mL}$ of DCM under argon atmosphere, then AgOTf $(0.02 \mathrm{~g}, 0.08 \mathrm{mmol})$ and $N$-iodosuccinimide $(0.14 \mathrm{~g}, 0.60 \mathrm{mmol})$ were simultaneously added. The reaction was vigorously stirred for $2 \mathrm{~h}$ after which it was stopped with saturated solution of sodium thiosulphate $(5.0 \mathrm{~mL})$ and then washed with $25.0 \mathrm{~mL}$ of saturated sodium thiosulphate solution (1 time), saturated sodium bicarbonate ( 3 times), water ( 1 time) and brine (1 time). The organic layer was then dried over anhydrous sodium sulphate and then concentrated under vac. The residue, was purified by flash chromatography using ethyl acetate/hexane mixture (4:6) to give the $\alpha$-anomer, $12(0.19 \mathrm{~g}, 0.31 \mathrm{mmol})$ as a white solid. Yield was 58\%. NMR data of 12: ${ }^{1} \mathrm{H}-\mathrm{NMR}(300 \mathrm{MHz}$, chloroform- $d$ ) $\delta 5.36-5.19$ (m, 2H, H-2, H-3), 5.04 (dd, $J=9.7,9.7$ Hz, 1H, H-4), 4.73 (d, J = 1.5 Hz, 1H, H-1), 3.93-3.84 (m, 1H, H-5), 3.79-3.63 (m, 1H), 3.61-3.34 (m, 9H), 2.12 (s, 3H), 2.02 (s, 3H), $1.96(\mathrm{~s}, 3 \mathrm{H}), 1.50-1.48$ (m, 2H), 1.23 (broad s, 26H, lipid tail), 1.20 (d, $J=6.2 \mathrm{~Hz}, 3 \mathrm{H}, \mathrm{H}-6), 0.85\left(\mathrm{t}, J=6.6 \mathrm{~Hz}, 3 \mathrm{H}\right.$, terminal lipid $\mathrm{CH}_{3}$ ). ${ }^{13} \mathrm{C}-\mathrm{NMR}\left(75 \mathrm{MHz}, \mathrm{CDCl}_{3}\right) \delta 170.01,169.92,169.87,97.58,78.94,71.78,71.12,69.80,69.67,69.12,67.35$, $66.34,58.20,31.89,29.66,29.62,29.47,29.33,26.09,22.65,20.85,20.74,20.67,17.39,14.08$. ES-MS: calcd: $\mathrm{C}_{32} \mathrm{H}_{58} \mathrm{O}_{10} \mathrm{Na}^{+} m / z: 625.4$, found $[\mathrm{M}+\mathrm{Na}]^{+} m / z: 624.8$.

1-Hexadecyl-2R-methoxyl-3-O- $\alpha$-L-rhamnopyranosyl-sn-glycerol (2)

Compound $12(0.19 \mathrm{~g}, 0.31 \mathrm{mmol})$ was dissolved in $15.0 \mathrm{~mL}$ of methanol, then catalytic amount of sodium methoxide was added and the reaction was vigorously stirred for $3 \mathrm{~h}$. The reaction was stopped by acidic ion exchange resin. The resin was filtered and the filtrate was concentrated under vacuum and the residue was purified by flash chromatography using ethyl acetate/hexane mixture (9:1) to give $2(0.11 \mathrm{~g}, 0.23 \mathrm{mmol})$ as a white solid. Yield was 75\%. NMR data of 2: ${ }^{1} \mathrm{H}-\mathrm{NMR}(300 \mathrm{MHz}$, chloroform- $d$ ) $\delta 4.78(\mathrm{~d}, J=1.1,1 \mathrm{H}, \mathrm{H}-1), 4.12(\mathrm{~s}, 3 \mathrm{H}, \mathrm{OH}$, rhamnose-OH), $3.97(\mathrm{dd}, J=1.1,3.3 \mathrm{~Hz}, 1 \mathrm{H}$, H-2), 3.83-3.63 (m, 3H), 3.63-3.53 (m, 1H), 3.53-3.36 (m, 9H), $1.56(\mathrm{~m}, 2 \mathrm{H}), 1.31(\mathrm{~d}, J=6.0 \mathrm{~Hz}, 3 \mathrm{H}, \mathrm{H}-6)$, 1.28 (broad s, 26H, lipid tail), $0.89\left(\mathrm{t}, J=6.5 \mathrm{~Hz}, 3 \mathrm{H}\right.$, terminal lipid $\left.\mathrm{CH}_{3}\right) .{ }^{13} \mathrm{C}-\mathrm{NMR}\left(75 \mathrm{MHz}, \mathrm{CDCl}_{3}\right) \delta$ 99.92, 79.03, 72.80, 71.84, 71.68, 70.89, 69.99, 68.24, 66.71, 58.04, 31.94, 29.72, 29.69, 29.37, 26.13, 22.70, 17.55, 14.12. MALDI-HRMS: calcd: $\mathrm{C}_{26} \mathrm{H}_{52} \mathrm{O}_{7} \mathrm{Na}^{+} \mathrm{m} / z: 499.3611$, found $[\mathrm{M}+\mathrm{Na}]^{+} m / z: 499.3615$.

3-Hexadecyloxy-2R-hydroxyl propyl-1-p-toluene sulphonate (14)

The lipid diol $13(2.00 \mathrm{~g}, 6.32 \mathrm{mmol})$ was dissolved in dissolved in $20 \mathrm{~mL} \mathrm{DCM}$, cooled to $0{ }^{\circ} \mathrm{C}$, then $\mathrm{Et}_{3} \mathrm{~N}(1.28 \mathrm{~g}, 1.80 \mathrm{~mL}$ ) was added followed by 4-toluenesulphonyl chloride $(1.33 \mathrm{~g}, 6.95 \mathrm{mmol})$ and DMAP $(0.04 \mathrm{~g}, 0.32 \mathrm{mmol})$. The temperature was allowed to increase to room temperature $\left(23^{\circ} \mathrm{C}\right)$ and the mixture was stirred for $4 \mathrm{~h}$. At the end of reaction, the mixture was diluted with ethyl $(60.0 \mathrm{~mL})$ acetate, washed with saturated aqueous ammonium chloride ( 3 times), brine ( 3 times). The organic layer was then dried over sodium sulphate, concentrated under vacuum and the residue was purified using flash chromatography using hexane/ethyl acetate (8:2) to give $\mathbf{1 4}(1.80 \mathrm{~g}, 3.80 \mathrm{mmol})$ as a white flaky solid. Yield was 60\%. NMR data of 14: ${ }^{1} \mathrm{H}$ NMR $(300 \mathrm{MHz}$, chloroform- $d) \delta 7.78(\mathrm{~d}, J=8.2 \mathrm{~Hz}$, $2 \mathrm{H}$, aromatic protons), $7.33(\mathrm{~d}, J=8.1 \mathrm{~Hz}, 2 \mathrm{H}$, aromatic protons), 4.11-4.00 (m, 2H, TsO-CH 2 ), 3.99-3.89 $(\mathrm{m}, 1 \mathrm{H}, \mathrm{HO}-\mathrm{CH}), 3.46-3.31(\mathrm{~m}, 4 \mathrm{H}), 2.80(\mathrm{~d}, \mathrm{~J}=5.4 \mathrm{~Hz}, 1 \mathrm{H}, \mathrm{OH}), 2.42(\mathrm{~s}, 3 \mathrm{H} \text {, toluene-CH })_{3}, 1.55-1.41$ $(\mathrm{m}, 2 \mathrm{H}), 1.25\left(\mathrm{~s}, 26 \mathrm{H}\right.$, Lipid tail), $0.87\left(\mathrm{t}, \mathrm{J}=6.4 \mathrm{~Hz}, 3 \mathrm{H}\right.$, lipid terminal- $\left.\mathrm{CH}_{3}\right) .{ }^{13} \mathrm{C}-\mathrm{NMR}\left(75 \mathrm{MHz} \mathrm{CDCl}_{3}\right)$ 
$\delta 144.90,132.77,129.88,127.99,71.73,70.77,70.56,68.25,31.93,29.71,29.68,29.64,29.61,29.48,29.37$, 26.01, 22.68, 21.58, 14.11. ES-MS: calcd: $\mathrm{C}_{26} \mathrm{H}_{46} \mathrm{NO}_{5} \mathrm{Na}^{+} m / z: 493.3$, found $[\mathrm{M}+\mathrm{Na}]^{+} m / z: 493.7$.

3-Hexadecyloxy-2R-hdroxyl propyl-1-azide (15)

Compound $14(1.30 \mathrm{~g}, 2.76 \mathrm{mmol})$ and sodium azide $(1.81 \mathrm{~g}, 27.60 \mathrm{mmol})$ were suspended in anhydrous DMF and the mixture was stirred at $90{ }^{\circ} \mathrm{C}$ for $18 \mathrm{~h}$. at the end of the reaction the mixture was concentrated then diluted with ethyl acetate and filtered to remove excess sodium azide. The filtrate was then concentrated and purified with flash chromatography using hexane/ethyl acetate (9:1) to give $15(0.85 \mathrm{~g}, 2.50 \mathrm{mmol})$ as a white wax like solid. Yield was $91 \% .{ }^{1} \mathrm{H}-\mathrm{NMR}$ (300 MHz, Chloroform- $d$ ) 反 3.92-3.86 (m, 1H, HO-CH), 3.48-3.34 (m, 4H), $3.31\left(\mathrm{dd}, J=5.5,2.9 \mathrm{~Hz}, 2 \mathrm{H},-\mathrm{CH}_{2} \mathrm{~N}_{3}\right), 3.17(\mathrm{~s}, 1 \mathrm{H}$, $\mathrm{OH}), 1.55-1.41(\mathrm{~m}, 2 \mathrm{H}, 1.25(\mathrm{~s}, 26 \mathrm{H}$, Lipid tail $)), 0.85\left(\mathrm{t}, J=6.6 \mathrm{~Hz}, 3 \mathrm{H}\right.$, terminal lipid- $\left.\mathrm{CH}_{3}\right) \cdot{ }^{13} \mathrm{C}-\mathrm{NMR}$ $\left(75 \mathrm{MHz}, \mathrm{CDCl}_{3}\right) \delta$ 71.92, 71.71, 69.59, 53.54, 31.93, 29.71, 29.67, 29.61, 29.52, 29.47, 29.37, 26.05, 22.67, 14.03.ES-MS: calcd: $\mathrm{C}_{19} \mathrm{H}_{39} \mathrm{~N}_{3} \mathrm{O}_{2} \mathrm{Na}^{+} m / z: 364.3$, found $[\mathrm{M}+\mathrm{Na}]^{+} \mathrm{m} / z: 364.5$.

3-Azido-1-hexadecyloxyl-2R-(2' $3^{\prime} 4^{\prime}$-tri-O-acetyl-O- $\alpha$-L-rhamnopyranosyl)-sn-glycerol (16)

The fully protected glycoside donor $10(0.15 \mathrm{~g}, 0.41 \mathrm{mmol})$ and the glycoside acceptor $15(0.12 \mathrm{~g}$, $0.36 \mathrm{mmol})$ were dissolved in $15.0 \mathrm{~mL}$ of DCM under argon atmosphere, then AgOTf $(0.02 \mathrm{~g}, 0.08$ $\mathrm{mmol})$ and $\mathrm{N}$-iodosuccinimide $(0.14 \mathrm{~g}, 0.60 \mathrm{mmol})$ were simultaneously added. The reaction was vigorously stirred for $2 \mathrm{~h}$ after which it was stopped with saturated solution of sodium thiosulphate $(5.0 \mathrm{~mL})$ and then washed with $25.0 \mathrm{~mL}$ of saturated sodium thiosulphate solution (1 time), saturated sodium bicarbonate ( 3 times), water ( 1 time) and brine ( 1 time). The organic layer was then dried over anhydrous sodium sulphate and then concentrated under vac. The residue was purified by flash chromatography using ethyl acetate/hexane mixture (4:6) to give $\alpha$-anomers, $\mathbf{1 6}(0.12 \mathrm{~g}, 0.20 \mathrm{mmol})$ as a white solid. Yield was $55 \%$. NMR data of 16: ${ }^{1} \mathrm{H}-\mathrm{NMR}(300 \mathrm{MHz}$, chloroform- $d$ ) $\delta 5.30$ (dd, $J=10.0$, $3.6 \mathrm{~Hz}, 1 \mathrm{H}, \mathrm{H}-3), 5.25(\mathrm{dd}, J=3.6,1.7 \mathrm{~Hz}, 1 \mathrm{H}, \mathrm{H}-2), 5.06(\mathrm{dd}, J=9.8,9.9 \mathrm{~Hz}, 1 \mathrm{H}, \mathrm{H}-4), 4.93(\mathrm{~d}, J=1.7 \mathrm{~Hz}$, 1H, H-1), 4.18-3.99 (m, 1H, H-5), 3.95-3.83 (m, 1H), 3.58-3.29 (m, 6H), $2.14(\mathrm{~s}, 3 \mathrm{H}), 2.03(\mathrm{~s}, 3 \mathrm{H}), 1.98(\mathrm{~s}$, $3 \mathrm{H}), 1.57-1.52(\mathrm{~m}, 2 \mathrm{H}), 1.25$ (broad s, 26H, lipid tail), $1.20(\mathrm{~d}, J=6.3 \mathrm{~Hz}, 3 \mathrm{H}, \mathrm{H}-6), 0.87(\mathrm{t}, J=6.6 \mathrm{~Hz}, 3 \mathrm{H})$. ${ }^{13} \mathrm{C}-\mathrm{NMR}\left(75 \mathrm{MHz}, \mathrm{CDCl}_{3}\right) \delta 170.01,169.95,169.84,97.22,76.46,71.77,71.09,70.48,70.01,68.92,66.68$, $51.68,31.91,29.68,29.49,29.34,26.13,20.87,20.75,20.67,17.34,14.09$. ES-MS: calcd: $\mathrm{C}_{31} \mathrm{H}_{55} \mathrm{~N}_{3} \mathrm{O}_{9} \mathrm{Na}^{+}$ $m / z: 636.4$, found $[\mathrm{M}+\mathrm{Na}]^{+} m / z: 636.5$.

3-Azido-1-hexadecyloxyl-2R-O- $\alpha$-L-rhamnopyranosyl-sn-glycerol (17)

Compound $16(0.12 \mathrm{~g}, 0.20 \mathrm{mmol})$ was dissolved in $15.0 \mathrm{~mL}$ of methanol, then catalytic amount of sodium methoxide was added and the reaction was vigorously stirred for $3 \mathrm{~h}$. The reaction was stopped by acidic ion exchange resin. The resin was filtered and the filtrate was concentrated under vacuum and the residue was purified by flash chromatography using ethyl acetate/hexane mixture $(9: 1)$ to give $17(0.08 \mathrm{~g}, 0.16 \mathrm{mmol})$ as a white solid. Yield was $79 \%$. NMR data of $17:{ }^{1} \mathrm{H}-\mathrm{NMR}(300 \mathrm{MHz}$, chloroform- $d$ ) $\delta 4.95(\mathrm{~d}, J=1.1,1 \mathrm{H}, \mathrm{H}-1), 4.19-3.95(\mathrm{~m}, 1 \mathrm{H}, \mathrm{H}-5), 4.03-3.85(\mathrm{~m}, 2 \mathrm{H}), 3.77(\mathrm{~d}, J=8.3$, $3.5 \mathrm{~Hz}, 1 \mathrm{H}, \mathrm{H}-3), 3.62-3.27(\mathrm{~m}, 10 \mathrm{H}), 1.58-1.54(\mathrm{~m}, 2 \mathrm{H}), 1.32(\mathrm{~d}, J=6.4 \mathrm{~Hz}, 3 \mathrm{H}, \mathrm{H}-6), 1.27$ (broad s, 26H), $0.88(\mathrm{~d}, J=7.1 \mathrm{~Hz}, 3 \mathrm{H}) .{ }^{13} \mathrm{C}-\mathrm{NMR}\left(75 \mathrm{MHz}, \mathrm{CDCl}_{3}\right) \delta 100.04,76.26,72.70,71.83,71.60,71.09,70.33$, $68.67,51.71,31.94,29.73,29.52,29.38,26.11,22.70,17.48,14.12$. ES-MS: calcd: $\mathrm{C}_{25} \mathrm{H}_{49} \mathrm{~N}_{3} \mathrm{O}_{6} \mathrm{Na}^{+} \mathrm{m} / z$ : 500.4, found $[\mathrm{M}+\mathrm{Na}]^{+} \mathrm{m} / z: 500.4$.

3-Amino-1-O-hexadecyloxy-2R-(O- $\alpha$-L-rhamnopyranosyl)-sn-glycerol (3)

To a solution compound $17(0.10 \mathrm{~g}, 0.21 \mathrm{mmol})$ in THF $(7.0 \mathrm{~mL})$ was added $1.5 \mathrm{~mL}$ of water and $2.6 \mathrm{~mL}$ of $1 \mathrm{M}$ trimethylphosphine in THF. The reaction was vigorously stirred for $2 \mathrm{~h}$ at room temperature after which it was concentrated under vac. The residue was purified by C-18 column using gradient elution with water/methanol to give $3(0.06 \mathrm{~g}, 0.13 \mathrm{mmol})$ as a white solid. Yield was 61\%. NMR data for 3: ${ }^{1} \mathrm{H}-\mathrm{NMR}\left(300 \mathrm{MHz}\right.$, methanol- $\left.d_{4}\right) \delta 4.65(\mathrm{~d}, J=1.31 \mathrm{H}, \mathrm{H}-1) 3.65(\mathrm{dd}, J=1.3$, $3.4 \mathrm{~Hz}, 1 \mathrm{H}, \mathrm{H}-2), 3.48-3.56$ (m, 2H), 3.45 (dd, J = 9.5, 3.4 Hz, 1H, H-3), 3.37-3.29 (m, 1H, H-5), 3.29-3.11 $(\mathrm{m}, 4 \mathrm{H}), 2.59-2.42(\mathrm{~m}, 2 \mathrm{H}), 1.40-1.34(\mathrm{~m}, 2 \mathrm{H}), 1.08$ (broad s, 29H, H-6, lipid tail), $0.69(\mathrm{t}, J=6.4 \mathrm{~Hz}, 3 \mathrm{H}$, 
lipid terminal- $\left.\mathrm{CH}_{3}\right) .{ }^{13} \mathrm{C}-\mathrm{NMR}(75 \mathrm{MHz}, \mathrm{MeOD}) \delta 101.91,79.55,73.98,72.69,72.66,72.45,72.39,70.10$, 43.50, 33.10, 30.81, 30.78, 30.66, 30.50, 27.33, 23.76, 18.08, 14.47. MALDI-HRMS: calcd: $\mathrm{C}_{25} \mathrm{H}_{51} \mathrm{NO}_{6} \mathrm{Na}^{+}$ $m / z: 484.3614$, found $[\mathrm{M}+\mathrm{Na}]^{+} \mathrm{m} / z: 484.3611$.

3-(-3-(p-Hydroxyphenylpropyl)-amido-1-O-Hexadecyloxy-2R-(O- $\alpha$-L-rhamnopyranosyl)-sn-glycerol (4)

To a solution of p-hydroxyphenyl propionic acid $18(0.02 \mathrm{~g}, 0.11 \mathrm{mmol}), \mathrm{TBTU}(0.05 \mathrm{~g}, 0.14 \mathrm{mmol})$ and diisopropyl ethyl amine $(0.02 \mathrm{~g}, 0.14 \mathrm{mmol})$ in $5.0 \mathrm{~mL}$ of DMF which has been stirring for $20 \mathrm{~min}$ was added $3(0.05 \mathrm{~g}, 0.11 \mathrm{mmol})$. The reaction was vigorously stirred for $8 \mathrm{~h}$ after which it was diluted with methanol. The solvents were removed in vacuo and the residue was purified by flash chromatography using ethylacetate to give $4(0.07 \mathrm{~g}, 0.11 \mathrm{mmmol})$ as an off white solid. Yield was $98 \%$. NMR data of $4:{ }^{1} \mathrm{H}-\mathrm{NMR}\left(300 \mathrm{MHz}\right.$, methanol- $\left.d_{4}\right) \delta 6.94(\mathrm{~d}, J=8.3 \mathrm{~Hz}, 2 \mathrm{H}$, aromatic proton), 6.62 $(\mathrm{d}, J=8.3 \mathrm{~Hz}, 2 \mathrm{H}$, aromatic proton), $4.72(\mathrm{~d}, J=1.9 \mathrm{~Hz}, 1 \mathrm{H}, \mathrm{H}-1), 3.80-3.62(\mathrm{~m}, 2 \mathrm{H}), 3.55(\mathrm{dd}, J=9.8$, $5.7 \mathrm{~Hz}, 1 \mathrm{H}), 3.41-3.21(\mathrm{~m}, 7 \mathrm{H}), 3.16(\mathrm{dd}, J=13.8,5.6 \mathrm{~Hz}, 1 \mathrm{H}), 2.73(\mathrm{t}, J=7.5 \mathrm{~Hz}, 2 \mathrm{H}$, propionamide $\left.\mathrm{CH}_{2}\right), 2.36\left(\mathrm{t}, J=7.7 \mathrm{~Hz}, 2 \mathrm{H}\right.$, propionamide $\left.\mathrm{CH}_{2}\right), 1.49-1.41(\mathrm{~m}, 2 \mathrm{H}), 1.21$ (broad s, 26H, lipid tail), 1.16 $(\mathrm{d}, J=6.2 \mathrm{~Hz}, 3 \mathrm{H}, \mathrm{H}-6), 0.82\left(\mathrm{t}, J=6.4 \mathrm{~Hz}, 3 \mathrm{H}\right.$, lipid terminal $\left.\mathrm{CH}_{3}\right) .{ }^{13} \mathrm{C}-\mathrm{NMR}(75 \mathrm{MHz}, \mathrm{MeOD}) \delta$ 175.67, 156.96, 132.79, 130.30, 116.30, 101.26, 76.32, 74.02, 72.67, 72.53, 72.34, 70.00, 49.89, 48.18, 40.92, $39.32,33.10,32.20,30.82,30.70,30.50,27.32,23.76,18.09,14.48$. MALDI-HRMS: calcd: $\mathrm{C}_{34} \mathrm{H}_{59} \mathrm{NO}_{7} \mathrm{Na}^{+}$ $m / z: 632.4138$, found $[\mathrm{M}+\mathrm{Na}]^{+} m / z: 632.4590$.

$\alpha / \beta$-L-Glucopyranosyl-1,2,3,4,5-pentaacetate (19)

L-Glucose $(0.90 \mathrm{~g}, 5.00 \mathrm{mmol})$ was dissolved in $20.0 \mathrm{~mL}$ pyridine at room temperature, then acetic anhydride $(5.20 \mathrm{~mL}, 54.90 \mathrm{mmol})$ and dimethyl amino pyridine $(0.10 \mathrm{~g}$, ) were sequentially added and the reaction was vigorously stirred for $18 \mathrm{~h}$ after which it was stopped by addition of methanol $(10.0 \mathrm{~mL})$ and then stirred for $15 \mathrm{~min}$. The solvents were removed under high vac. The resulting residue was then dissolved in ethyl acetate $(50.0 \mathrm{~mL}$ ) and washed with $3 \% \mathrm{HCl}$ solution (1 time), saturated sodium bicarbonate ( 2 times), distilled water (1 time) and brine (1 time). The resulting organic layer was dried over $\mathrm{Na}_{2} \mathrm{SO}_{4}$ and concentrated to dryness and purified by flash chromatography using ethyl acetate and hexane (1:1) to give $19(1.70 \mathrm{~g}, 4.40 \mathrm{mmol})$ as $\alpha, \beta$ mixture (3:2). Yield was $88 \%$. Characteristic proton NMR data for 19: ${ }^{1} \mathrm{H}-\mathrm{NMR}(300 \mathrm{MHz}$, chloroform- $d) \delta 6.35(\mathrm{~d}, J=3.7 \mathrm{~Hz}, 3 \mathrm{H}, \alpha-\mathrm{H}-1), 5.73(\mathrm{~d}$, $J=8.2 \mathrm{~Hz}, 2 \mathrm{H}, \beta-\mathrm{H}-1)$. ES-MS: calcd: $\mathrm{C}_{16} \mathrm{H}_{22} \mathrm{O}_{11} \mathrm{Na}^{+} m / z: 413.1$, found $[\mathrm{M}+\mathrm{Na}]^{+} m / z: 413.4$.

Phenyl-2,3,4,6-tetra-O-acetyl-1-thio- $\beta$-L-glucopyranoside (20)

The pentaaacetate $19(1.70 \mathrm{~g}, 4.40 \mathrm{mmol})$ was dissolved in in $20.0 \mathrm{~mL}$ DCM, then thiophenol $(0.68 \mathrm{~g}, 6.14 \mathrm{mmol})$ and $\mathrm{BF}_{3} \cdot \mathrm{Et}_{2} \mathrm{O}(0.87 \mathrm{~g}, 6.14 \mathrm{mmol})$ were sequentially added. The reaction was stirred vigorously for $18 \mathrm{~h}$ after which it was stopped with $20.0 \mathrm{~mL}$ saturated sodium bicarbonate at $0{ }^{\circ} \mathrm{C}$. The organic layer was separated using separatory funnel and subsequently washed with saturated $20.0 \mathrm{~mL}$ of sodium bicarbonate ( 2 times), $20.0 \mathrm{~mL}$ of water (1 time) and $20.0 \mathrm{~mL}$ of brine (1 time). The organic layer was dried over anhydrous sodium bicarbonate and then concentrated in vacuo. The residue was then partially purified by flash chromatography using ethyl acetate and hexane (4:6) to give mainly $\beta$-anomer of $\mathbf{2 0}(1.72 \mathrm{~g}, 4.50 \mathrm{mmol})$. Yield was $88 \%$. Compound 20 was not characterised.

3-Azido-1-hexadecyloxyl-2R-(2' $3^{\prime} 4^{\prime} 6^{\prime}$-tetra-O-acetyl-O- $\beta$-L-glucopyranosyl)-sn-glycerol (21)

The fully protected glycoside donor $20(0.18 \mathrm{~g}, 0.40 \mathrm{mmol})$ and the glycoside acceptor $15(0.15 \mathrm{~g}$, $0.44 \mathrm{mmol})$ were dissolved in $15.0 \mathrm{~mL}$ of DCM under argon atmosphere, then AgOTf $(0.02 \mathrm{~g}, 0.08 \mathrm{mmol})$ and $\mathrm{N}$-iodosuccinimide $(0.18 \mathrm{~g}, 0.80 \mathrm{mmol})$ were simultaneously added. The reaction was vigorously stirred for $2 \mathrm{~h}$ after which it was stopped with saturated solution of sodium thiosulphate $(5.0 \mathrm{~mL})$ and then washed with $25.0 \mathrm{~mL}$ of saturated sodium thiosulphate solution (1 time), saturated sodium bicarbonate ( 3 times), water ( 1 time) and brine ( 1 time). The organic layer was then dried over anhydrous sodium sulphate and then concentrated under vac. The residue was purified by flash chromatography using ethyl acetate/hexane mixture (4:6) to give $21(0.13 \mathrm{~g}, 0.20 \mathrm{mmol})$ as a white solid. 
Yield was 50\%. ${ }^{1} \mathrm{H}-\mathrm{NMR}(300 \mathrm{MHz}$, chloroform-d) $\delta 5.22(\mathrm{dd}, J=9.4,9.4 \mathrm{~Hz}, 1 \mathrm{H}, \mathrm{H}-4), 5.10(\mathrm{dd}, J=9.6$, $9.6 \mathrm{~Hz}, 1 \mathrm{H}, \mathrm{H}-3), 4.97$ (dd, $J=9.6,7.9 \mathrm{~Hz} 1 \mathrm{H}, \mathrm{H}-2), 4.75$ (d, J = 7.9 Hz, 1H, H-1), 4.25-4.18 (m, 2H), 4.02-3.90 (m, 1H), 3.78-3.69 (m, 1H), 3.53-3.23 (m, 6H), $2.10(\mathrm{~s}, 3 \mathrm{H}), 2.05(\mathrm{~s}, 3 \mathrm{H}), 2.04(\mathrm{~s}, 3 \mathrm{H}), 2.02(\mathrm{~s}$, $3 \mathrm{H}), 1.59-1.52(\mathrm{~m}, 2 \mathrm{H}), 1.27$ (broad singlet, 26H, Lipid tail), 0.89 (h, $J=6.1 \mathrm{~Hz}, 3 \mathrm{H}$, Lipid terminal- $\mathrm{CH}_{3}$ ). ${ }^{13} \mathrm{C}-\mathrm{NMR}\left(75 \mathrm{MHz}_{\mathrm{CDCl}}\right) \delta$ 170.65, 170.29, 169.37, 169.17, 100.44, 77.64, 72.83, 71.93, 71.85, 71.47, 70.58, $68.47,61.90,52.06,31.93,29.70,29.66,29.61,29.49,29.36,26.12,22.70,20.72,20.62,14.12$. ES-MS: calcd: $\mathrm{C}_{33} \mathrm{H}_{57} \mathrm{~N}_{3} \mathrm{O}_{11} \mathrm{Na}^{+} m / z: 694.4$, found $[\mathrm{M}+\mathrm{Na}]^{+} m / z: 694.8$.

3-Azido-1-hexadecyloxyl-2R-O- $\beta$-L-glucopyranosyl-sn-glycerol (22)

Compound $21(0.13 \mathrm{~g}, 0.20 \mathrm{mmol})$ was dissolved in $15.0 \mathrm{~mL}$ of methanol, then the catalytic amount of sodium methoxide was added and the reaction was vigorously stirred for $3 \mathrm{~h}$. The reaction was stopped by acidic ion exchange resin. The resin was filtered and the filtrate was concentrated under vacuum and the residue was dissolved in ethyl acetate and filtered through a pad of silica gel to give $22(0.09 \mathrm{~g}, 0.17 \mathrm{mmol})$ as a white solid. Yield was 84\%. Compound 22 was not characterised. ES-MS: calcd: $\mathrm{C}_{25} \mathrm{H}_{49} \mathrm{~N}_{3} \mathrm{O}_{7} \mathrm{Na}^{+} m / z: 526.4$, found $[\mathrm{M}+\mathrm{Na}]^{+} m / z: 526.5$.

3-Amino-1-hexadecyloxyl-2R-O- $\beta$-L-glucopyranosyl-sn-glycerol (5)

To a solution of compound $22(0.09 \mathrm{~g}, 0.17 \mathrm{mmol})$ in THF $(7.0 \mathrm{~mL})$ was added $1.5 .0 \mathrm{~mL}$ of water and $2.6 \mathrm{~mL}$ of $1 \mathrm{M}$ trimethylphosphine in THF. The reaction was vigorously stirred for $2 \mathrm{~h}$ at room temperature after which it was concentrated under vac. The residue was purified by $\mathrm{C}-18$ column using gradient elution with water/methanol to give $5(0.06 \mathrm{~g}, 0.09 \mathrm{mmol})$ as a white solid. Yield was 55\%. NMR data for 5: ${ }^{1} \mathrm{H}-\mathrm{NMR}\left(300 \mathrm{MHz}\right.$, methanol- $\left.d_{4}\right) \delta 4.35$ (d, J = 7.7, Hz, 1H, H-1), 3.81 (dd, $\left.J=13.7,3.6 \mathrm{~Hz}, 2 \mathrm{H},-\mathrm{CH}-\mathrm{CH}_{2} \mathrm{O}-\right)$, 3.69-3.36 (m, 6H), 3.34-3.07 (m, 4H), 1.59-1.38 (m, 3H), 1.22 (broad $\mathrm{s}, 26 \mathrm{H}$, Lipid tail), $0.85\left(\mathrm{t}, J=7.3,3 \mathrm{H}\right.$, Lipid terminal- $\left.\mathrm{CH}_{3}\right) .{ }^{13} \mathrm{C}-\mathrm{NMR}(75 \mathrm{MHz}, \mathrm{MeOD}) \delta 103.87$, 79.65, 78.17, 77.96, 75.13, 72.76, 72.35, 71.66, 62.80, 43.87, 33.09, 30.81, 30.78, 30.49, 27.26, 23.75, 14.46 . MALDI-HRMS: calcd: $\mathrm{C}_{25} \mathrm{H}_{51} \mathrm{NO}_{7} \mathrm{Na}^{+} m / z: 500.3563$, found $[\mathrm{M}+\mathrm{Na}]^{+} m / z: 500.3740$.

\section{1,2,3,4,6-Pentaacetyl $\alpha / \beta$-L-mannopyranoside (23)}

L-Mannose $(2.00 \mathrm{~g}, 11.10 \mathrm{mmol})$, was dissolved in pyridine $(40.0 \mathrm{~mL})$, then acetic anhydride $(11.00$ $\mathrm{mL}, 111.00 \mathrm{mmol}$ ) was added followed by dimethyl amino pyridine (DMAP, $0.27 \mathrm{~g} 2.20 \mathrm{mmol}$ ). The mixture was stirred vigorously for $18 \mathrm{~h}$ at room temperature and it was stopped by addition of methanol $(10.0 \mathrm{~mL})$ and then stirred for $15 \mathrm{~min}$. The solvents were removed under high vac. The resulting residue was then dissolved in ethyl acetate $(50.0 \mathrm{~mL})$ and washed with $3 \% \mathrm{HCl}$ solution (1 time), saturated sodium bicarbonate ( 2 times), distilled water ( 1 time) and brine ( 1 time). The resulting organic layer was dried over $\mathrm{Na}_{2} \mathrm{SO}_{4}$ and concentrated to dryness and purified by flash chromatography using ethyl acetate and hexane (1:1) to give 23 (3.70 g, $9.48 \mathrm{mmol})$ as $\alpha, \beta$ mixture (4:1). Yield was 85\%. NMR data for $\alpha$ - anomer of compound 23: ${ }^{1} \mathrm{H}-\mathrm{NMR}(300 \mathrm{MHz}$, chloroform- $d) \delta 5.94(\mathrm{~d}, J=1.9 \mathrm{~Hz}, 1 \mathrm{H}, \mathrm{H}-1)$, 5.24-5.06 (m, 3H, H-2), 4.14 (dd, $J=12.7,4.9$ Hz, 1H, H-6a ), 4.05-3.85 (m, 2H, H-5, H-6 $), 2.09$ (s, 3H), $2.01(\mathrm{~s}, 3 \mathrm{H}), 1.96(\mathrm{~s}, 3 \mathrm{H}), 1.92(\mathrm{~s}, 3 \mathrm{H}), 1.82(\mathrm{~s}, 3 \mathrm{H}) .{ }^{13} \mathrm{C}-\mathrm{NMR}\left(75 \mathrm{MHz}, \mathrm{CDCl}_{3}\right) \delta 170.34,169.73,169.50$, 169.34, 167.88, 90.44, 70.45, 68.63, 68.20, 65.39, 61.94, 20.62, 20.53, 20.48, 20.44, 20.41. ES-MS: calcd: $\mathrm{C}_{16} \mathrm{H}_{22} \mathrm{O}_{11} \mathrm{Na}^{+} m / z: 414.1$, found $[\mathrm{M}+\mathrm{Na}]^{+} m / z: 414.5$.

Phenyl-2,3,4,6-tetra-O-acetyl-1-thio- $\alpha$-L-mannopyranoside (24)

The pentaaacetate $23(1.50 \mathrm{~g}, 3.35 \mathrm{mmol})$ was dissolved in in $30.0 \mathrm{~mL}$ DCM, then thiophenol $(1.30 \mathrm{~g}, 11.50 \mathrm{mmol})$ and $\mathrm{BF}_{3} \cdot \mathrm{Et}_{2} \mathrm{O}(1.60 \mathrm{~g}, 11.50 \mathrm{mmol})$ were sequentially added. The reaction was stirred vigorously for $18 \mathrm{~h}$ after which it was stopped with $30 \mathrm{~mL}$ saturated sodium bicarbonate at $0{ }^{\circ} \mathrm{C}$. The organic layer was separated using separatory funnel and subsequently washed with saturated $35.0 \mathrm{~mL}$ of sodium bicarbonate (2 times), $30.0 \mathrm{~mL}$ of water (1 time) and $30.0 \mathrm{~mL}$ of brine (1 time). The organic layer was dried over anhydrous sodium bicarbonate and then concentrated in vacuo. The residue was then purified by flash chromatography using ethyl acetate and hexane (4:6) to give 
mainly $\alpha$-anomer of $24(0.99 \mathrm{~g}, 2.35 \mathrm{mmol})$. Yield was 70\%. NMR data of compound 24 is similar to previously reported data [6]. ES-MS: calcd: $\mathrm{C}_{20} \mathrm{H}_{24} \mathrm{O}_{9} \mathrm{Na}^{+} \mathrm{m} / z: 463.1$, found [M + Na] ${ }^{+} \mathrm{m} / z: 462.9$.

Phenyl-1-thio- $\alpha$-L-mannopyranoside (25)

Compound $24(1.00 \mathrm{~g}, 2.35 \mathrm{mmol})$ was dissolved in $15.0 \mathrm{~mL}$ of methanol, then catalytic amount of sodium methoxide was added and the reaction was vigorously stirred for $3 \mathrm{~h}$. The reaction was stopped by acidic ion exchange resin. The resin was filtered and the filtrate was concentrated under vacuum and the residue was dissolved in ethyl acetate and filtered again through a pad of silica gel to give $25(0.58 \mathrm{~g}, 2.14 \mathrm{mmol})$ as a white solid. Yield was 91\%. This compound was used without further purification and characterization for the next step.

Phenyl-6-tosyl-1-thio- $\alpha$-L-mannopyranoside (26)

Compound 25 (1.31 g, $4.80 \mathrm{mmol})$ was dissolved in dissolved in $20.0 \mathrm{~mL}$ pyridine, cooled to $0{ }^{\circ} \mathrm{C}$, then toluenesulphonychloride $(1.06 \mathrm{~g}, 5.54 \mathrm{mmol})$ and DMAP $(0.05 \mathrm{~g}, 0.41 \mathrm{mmol})$ were added. The temperature was allowed to increase to room temperature and the mixture was stirred for $18 \mathrm{~h}$. At the end of reaction, the mixture was diluted with methanol after which the solvents were removed in vacuo. The residue was diluted with $40.0 \mathrm{~mL}$ ethyl acetate and the washed sodium bicarbonate solution (3 times), brine (3 times). The organic layer was then dried over sodium sulphate and then concentrated under vacuum and the residue was partially purified by flash chromatography using ethyl acetate $(100 \%)$ to give $26(1.81 \mathrm{~g}, 4.24 \mathrm{mmol})$ as a white solid. Yield was $88 \%$. 26 was not characterized using NMR. ES-MS: calcd: $\mathrm{C}_{19} \mathrm{H}_{22} \mathrm{O}_{7} \mathrm{~S}_{2} \mathrm{Na}^{+} \mathrm{m} / z$ : 449.1, found [M + Na] ${ }^{+} \mathrm{m} / z: 449.5$.

Phenyl-6-azido-1-thio- $\alpha$-L-mannopyranoside (27)

Compound 26 ( $1.81 \mathrm{~g}, 4.24 \mathrm{mmol})$ and sodium azide $(1.80 \mathrm{~g}, 27.60 \mathrm{mmol})$ were suspended in anhydrous DMF and the mixture was stirred at $90{ }^{\circ} \mathrm{C}$ for $18 \mathrm{~h}$. at the end of the reaction the mixture was concentrated then diluted with ethyl acetate and filtered to remove excess sodium azide. The filtrate was then concentrated and partially purified with flash chromatography using hexane/ethyl acetate (1:9) to give $27(1.20 \mathrm{~g}, 4.04 \mathrm{mmol})$ as a white solid. Yield was 95\%. ES-MS: calcd: $\mathrm{C}_{12} \mathrm{H}_{15} \mathrm{~N}_{3} \mathrm{O}_{4} \mathrm{SNa}^{+}$ $m / z: 320.1$, found $[\mathrm{M}+\mathrm{Na}]^{+} \mathrm{m} / z: 320.3$

Phenyl-2,3,4-tri-O-acetyl-6-azido-1-thio- $\alpha$-L-mannopyranoside (28)

Compound $27(1.20 \mathrm{~g}, 4.04 \mathrm{mmol})$ was dissolved in pyridine $(50.0 \mathrm{~mL})$, then acetic anhydride ( $2.00 \mathrm{~mL}, 20.00 \mathrm{mmol}$ ) was added followed by dimethyl amino pyridine (DMAP, $0.05 \mathrm{~g}, 0.41 \mathrm{mmol}$ ). The mixture was stirred vigorously for $18 \mathrm{~h}$ at room temperature and it was stopped by addition of methanol $(10.0 \mathrm{~mL})$ and then stirred for $15 \mathrm{~min}$. The solvents were removed under high vac. The resulting residue was then dissolved in ethyl acetate $(50.0 \mathrm{~mL})$ and washed with $3 \% \mathrm{HCl}$ solution ( 1 time), saturated sodium bicarbonate ( 2 times), distilled water ( 1 time) and brine ( 1 time). The resulting organic layer was dried over $\mathrm{Na}_{2} \mathrm{SO}_{4}$ and concentrated to dryness and purified by flash chromatography using ethyl acetate and hexane (1:1) to give $\mathbf{2 8}(1.31 \mathrm{~g}, 3.10 \mathrm{mmol})$ white solid. Yield was $76 \%$. NMR data of compound 28: ${ }^{1} \mathrm{H}-\mathrm{NMR}(300 \mathrm{MHz}$, chloroform- $d$ ) $\delta 7.54-7.10(\mathrm{~m}, \mathrm{H}$, aromatic protons), 5.54-5.37 (m, 2H, H-1, H-3), 5.32-5.19 (m, 2H, H-2, H-4), 4.43-4.38 (m, 1H, H-5), 3.41-3.17 (m, 2H, H-6), 2.07 (s, $3 \mathrm{H}), 2.03(\mathrm{~s}, 3 \mathrm{H}), 1.90(\mathrm{~s}, 3 \mathrm{H}) .{ }^{13} \mathrm{C}-\mathrm{NMR}\left(75 \mathrm{MHz}, \mathrm{CDCl}_{3}\right) \delta 169.72,169.64,132.49,132.01,129.27,128.12$, 85.64, 71.01, 70.81, 69.18, 67.14, 50.98, 20.69, 20.58, 20.50. ES-MS: calcd: $\mathrm{C}_{18} \mathrm{H}_{21} \mathrm{~N}_{3} \mathrm{O}_{7} \mathrm{SNa}^{+} \mathrm{m} / z: 446.1$, found $[\mathrm{M}+\mathrm{Na}]^{+} \mathrm{m} / z: 446.4$.

\section{3-Azido-1-hexadecyloxyl-2R-(6' -azido-2' $3^{\prime} 4^{\prime}$-tri-O-acetyl-O- $\alpha$-L-mannopyranosyl)-sn-glycerol (29)}

The fully protected glycoside donor $28(0.20 \mathrm{~g}, 0.47 \mathrm{mmol})$ and the glycoside acceptor $15(0.18 \mathrm{~g}$, $0.52 \mathrm{mmol})$ were dissolved in $15.0 \mathrm{~mL}$ of DCM under argon atmosphere, then AgOTf $(0.02 \mathrm{~g}, 0.09 \mathrm{mmol})$ and $\mathrm{N}$-iodosuccinimide $(0.16 \mathrm{~g}, 0.71 \mathrm{mmol})$ were simultaneously added. The reaction was vigorously stirred for $2 \mathrm{~h}$ after which it was stopped with saturated solution of sodium thiosulphate $(5.0 \mathrm{~mL})$ and then washed with $25.0 \mathrm{~mL}$ of saturated sodium thiosulphate solution (1 time), saturated sodium 
bicarbonate ( 3 times), water ( 1 time) and brine ( 1 time). The organic layer was then dried over anhydrous sodium sulphate and then concentrated under vac. The residue was purified by flash chromatography using ethyl acetate/hexane mixture (4:6) to give $29(0.220 \mathrm{~g}, 0.34 \mathrm{mmol})$ as a white solid. Yield was 71\%. NMR data of 29: ${ }^{1} \mathrm{H}-\mathrm{NMR}(300 \mathrm{MHz}$, chloroform- $d$ ) $\delta 5.38(\mathrm{dd}, J=9.9,3.3 \mathrm{~Hz}$, $1 \mathrm{H}, \mathrm{H}-3), 5.32-5.20$ (m, 2H, H-2, H-4), 5.06 (d, $J=1.8 \mathrm{~Hz}, 1 \mathrm{H}, \mathrm{H}-1), 4.20$ (ddd, $J=9.5,5.6,3.4 \mathrm{~Hz}, 1 \mathrm{H}$, $\mathrm{H}-5), 4.07-3.89(\mathrm{~m}, 1 \mathrm{H}), 3.64-3.23(\mathrm{~m}, 8 \mathrm{H}, \mathrm{H}-6), 2.18(\mathrm{~s}, 3 \mathrm{H}), 2.06(\mathrm{~s}, 3 \mathrm{H}), 2.01(\mathrm{~s}, 3 \mathrm{H}), 1.61-1.54(\mathrm{~m}, 2 \mathrm{H})$, 1.27 (broad s, 26H, lipid tail), $0.89\left(\mathrm{t}, J=6.5 \mathrm{~Hz}, 3 \mathrm{H}\right.$, lipid terminal- $\left.\mathrm{CH}_{3}\right) .{ }^{13} \mathrm{C}-\mathrm{NMR}\left(75 \mathrm{MHz}, \mathrm{CDCl}_{3}\right) \delta$ 170.01, 169.81, 97.13, 76.84, 71.80, 70.35, 70.23, 69.69, 68.66, 67.20, 51.76, 51.18, 31.93, 29.70, 29.64, 29.52, 29.37, 26.15, 22.70, 20.88, 20.72, 14.12. ES-MS: calcd: $\mathrm{C}_{31} \mathrm{H}_{54} \mathrm{~N}_{6} \mathrm{O}_{9} \mathrm{Na}^{+} m / z: 677.4$, found $[\mathrm{M}+\mathrm{Na}]^{+} m / z$ : 677.8 .

3-Azido-1-hexadecyloxyl-2R-(6'-azido-O- $\alpha$-L-mannopyranosyl)-sn-glycerol (30)

Compound $29(0.22 \mathrm{~g}, 0.34 \mathrm{mmol})$ was dissolved in $15.0 \mathrm{~mL}$ of methanol, then catalytic amount of sodium methoxide $(0.05 \mathrm{~g})$ was added and the reaction was vigorously stirred for $3 \mathrm{~h}$. The reaction was stopped by acidic ion exchange resin. The resin was filtered and the filtrate was concentrated under vacuum and the residue was purified by flash chromatography using ethyl acetate/hexane mixture $(9: 1)$ to give $30(0.120 \mathrm{~g}, 0.23 \mathrm{mmol})$ as a white solid. Yield was $68 \%$. NMR data of 30 : ${ }^{1} \mathrm{H}-\mathrm{NMR}(300 \mathrm{MHz}$, methanol- $\left.d_{4}\right) \delta 5.02(\mathrm{~d}, J=1.9 \mathrm{~Hz}, 1 \mathrm{H}, \mathrm{H}-1), 4.10-3.89(\mathrm{~m}, 2 \mathrm{H}, \mathrm{H}-3), 3.96-3.81$ (m, 2H, H-2), 3.78-3.57 $(\mathrm{m}, 3 \mathrm{H}), 3.56-3.28(\mathrm{~m}, 6 \mathrm{H}), 1.62-1.58(\mathrm{~m}, 2 \mathrm{H}), 1.33$ (broad s, 26H, lipid tail), $0.91(\mathrm{t}, J=6.6 \mathrm{~Hz}, 3 \mathrm{H}$, lipid terminal- $\left.\mathrm{CH}_{3}\right) .{ }^{13} \mathrm{C}-\mathrm{NMR}(75 \mathrm{MHz}, \mathrm{MeOD}) \delta 101.93,77.92,74.29,72.72,72.18,72.15,71.65,69.45,53.23$, 52.92, 33.16, 30.89, 30.79, 30.57, 27.33, 23.82, 14.59. ES-MS: calcd: $\mathrm{C}_{25} \mathrm{H}_{48} \mathrm{~N}_{6} \mathrm{O}_{6} \mathrm{Na}^{+} m / z: 528.4$, found $[\mathrm{M}+\mathrm{Na}]^{+} m / z: 528.7$.

3-Amino-1-hexadecyloxyl-2R-(6'-amino-6' deoxy-O- $\alpha$-L-mannopyranosyl)-sn-glycerol (6)

To a solution of compound $30(0.12 \mathrm{~g}, 0.23 \mathrm{mmol})$ in THF $(7.0 \mathrm{~mL})$ was added $1.5 \mathrm{~mL}$ of water and $2.6 \mathrm{~mL}$ of $1 \mathrm{M}$ trimethylphosphine in THF. The reaction was vigorously stirred for $2 \mathrm{~h}$ at room temperature after which it was concentrated under vacuum. The residue was purified by C-18 column using gradient elution with water/methanol to give $6(0.07 \mathrm{~g}, 0.14 \mathrm{mmol})$ as a white solid. Yield was 62\%. NMR data for 6: ${ }^{1} \mathrm{H}-\mathrm{NMR}\left(300 \mathrm{MHz}\right.$, methanol- $\left.d_{4}\right) \delta 4.83(\mathrm{~d}, J=2.0 \mathrm{~Hz}, 1 \mathrm{H}, \mathrm{H}-1), 3.79$ (dd, $J=5.0,2.0 \mathrm{~Hz}, 1 \mathrm{H}, \mathrm{H}-2), 3.71-3.62(\mathrm{~m}, 2 \mathrm{H}), 3.58-3.43(\mathrm{~m}, 3 \mathrm{H}, \mathrm{H}-5), 3.38-3.17(\mathrm{~m}, 4 \mathrm{H}), 2.94-2.82(\mathrm{~m}$, $1 \mathrm{H}), 2.83-2.60(\mathrm{~m}, 2 \mathrm{H}, \mathrm{H}-6), 1.59-1.38(\mathrm{~m}, 2 \mathrm{H}), 1.21$ (broad s, $26 \mathrm{H}$, lipid tail), $0.83(\mathrm{t}, J=6.6 \mathrm{~Hz}, 3 \mathrm{H}$, lipid terminal- $\left.\mathrm{CH}_{3}\right) .{ }^{13} \mathrm{C}-\mathrm{NMR}(75 \mathrm{MHz}, \mathrm{MeOD}) \delta 101.52,79.00,74.36,72.75,72.70,72.44,72.34,69.51$, $43.45,43.26,33.12,30.84,30.70,30.52,27.37,23.78,14.51$. MALDI-HRMS: calcd: $\mathrm{C}_{25} \mathrm{H}_{52} \mathrm{~N}_{2} \mathrm{O}_{6} \mathrm{Na}^{+} \mathrm{m} / z$ : 499.3723, found $[\mathrm{M}+\mathrm{Na}]^{+} \mathrm{m} / z: 499.3409$.

\subsection{Biological Methods}

\subsubsection{Determination of Cytotoxicity of GAELs on Cancer Cell Lines}

The cell lines were cultured from frozen stocks originally obtained from ATCC (Manassas, VA, USA). MDA-MB-231, JIMT-1, DU145, MDA-MB-468, Hs578t and MDA-MB-453 were grown in DMEM medium supplemented with 10\% FBS. BT-474 cells were grown in DMEM/F12 medium supplemented with $10 \%$ FBS. MiaPaCa2 was cultured in DMEM supplemented with $10 \%$ FBS and $2.5 \%$ horse serum. All the media contained penicillin/streptomycin. U-251 and U-87 in Eagle MEM supplemented by $10 \%$ FBS, $1 \%$ Non-essential amino acids, $1 \mathrm{mM}$ sodium pyruvate and $2 \mathrm{mM}$ glutamine. BT- 549 was cultured in RPMI 1640 medium supplemented with 10\% FBS.

The effects of the GAELs on the viability of the epithelial cancer cell lines were determined as previously described $[4,6,7]$. Briefly, equal numbers of the cells were dispersed into 96-well plates. After $24 \mathrm{~h}$, the cells were incubated with the compounds $(0-30 \mu \mathrm{M})$ for $48 \mathrm{~h}$. MTS reagent [3-(4,5-dimethylthiazol-2-yl)-5-(3-carboxymethoxyphenyl)-2-(4-sulfophenyl)-2H-tetrazolium, inner salt; Promega, Madison, WI, USA] $(20 \% v / v)$ was subsequently added and the plates were incubated for $1-4 \mathrm{~h}$ in a $\mathrm{CO}_{2}$ incubator followed by measurement of the medium at $\mathrm{OD}_{490}$ with a plate reader 
(Molecular Devices). Wells with media but no cells were treated in similar fashion and the values utilized as blank. The results represent the mean \pm standard deviation of 6 independent determinations.

\subsubsection{Determination of Membranolytic Effects of GAELs}

Equal numbers of JIMT-1 and DU145 cells were dispersed into 96-well plates. After $24 \mathrm{~h}$ the cells were incubated with varying concentration of compounds 3 or 4 (4-6 $\mu \mathrm{M})$ for 5-6 h. Subsequently, $2 \mu \mathrm{M}$ of the cell membrane impermeant dye, ethidium homodimer-1 (EthD-1 (Molecular Probes, Eugene, OR, USA) that emits red fluorescence upon binding to DNA was added and the cells analysed by fluorescence microscopy. EthD-1 staining was compared to negative controls with no treatment and positive control treated with $0.01 \%$ Triton X-100 for $10 \mathrm{~min}$.

\subsubsection{Demonstration of Caspase-mediated-apoptosis Independent Mode of Cell Death}

Equal numbers of JIMT-1, or DU145 cells were dispersed into 96-well plates, and after $4 \mathrm{~h}$ the cells were treated with pan-caspase inhibitor QVD-OPh $(40 \mu \mathrm{M})$. After $20 \mathrm{~h}$, the cells were incubated with the varying concentration of the compounds $(0-9 \mu \mathrm{M})$ for $48 \mathrm{~h}$. At the end of the incubation, the MTS assay was used to assess cell viability as described above. The results represent the mean \pm standard deviation of 6 independent determinations.

\subsubsection{Hemolytic Assay}

The hemolytic activity of the GAEL analogs was evaluated using ovine erythrocyte. Sheep whole blood was collected from a slaughter house into a vessel containing disodium EDTA (1.2 g/mL) in a buffered saline (10 mM Tris, $150 \mathrm{mM} \mathrm{NaCl}$, pH 7.4). The erythrocytes were prepared and washed with buffered saline as previously reported [4]. For the assay, the erythrocyte suspension, varying amounts of the GAEL drugs or vehicle were pipetted into $1.5 \mathrm{~mL}$ microcentrifuge tubes to give a final volume of $1500 \mu \mathrm{L}$ and cell density of $2.5 \times 10^{8}$ cells $/ \mathrm{mL}$. The suspensions were incubated with gentle shaking in Eppendorf thermomixer for $30 \mathrm{~min}$. The $1.5 \mathrm{~mL}$ microcentrifuge tubes were cooled in ice water and centrifuged at $2000 \times \mathrm{g}$ and $4{ }^{\circ} \mathrm{C}$ for $5 \mathrm{~min}$ to pellet cell debris. $200 \mu \mathrm{L}$ of the supernatant was dissolved in $1800 \mu \mathrm{L}$ of $0.5 \% \mathrm{NH}_{4} \mathrm{OH}$ and the optical density (OD) was recorded using $1 \mathrm{~mL}$ cuvette at $540 \mathrm{~nm}$ in a spectrophotometer. For $0 \%$ hemolysis, buffer and vehicle were added instead of the drug, and $1 \% \mathrm{NH}_{4} \mathrm{OH}$ was used to generate $100 \%$ hemolysis. The $\%$ hemolysis was calculated using the optical density (OD) values as shown below in Equation (1) [4]:

$$
\% \text { hemolysis }=(\mathrm{X}-0 \%) /(100 \%-0 \%)
$$

where $X$ is the OD values of the drug(s) at varying concentration.

\subsubsection{Statistical Analysis}

The results represent the mean \pm standard deviation of 6 independent determinations. Statistical significant difference test was carried using GraphPadInstat software (GraphPad Software, San Diego, CA, USA). The mean values were subjected to one-way analysis of variance (ANOVA) followed by Tukey-Kramer multiple comparison post hoc test. Comparisons were carried out between the viability of controls and drug treated cells to determine if statistically significant differences existed between the two groups. The results of the effects of different concentrations of the compounds were also compared for statistically significant differences to determine if the cytotoxic activities of the drugs are dose dependent. The anticancer activities of all the compounds $\mathbf{2}-\mathbf{6}$ tested were compared using ANOVA followed by Tukey-Kramer multiple comparison tests at the following concentrations: 5, 7.5 and $10 \mu \mathrm{M}$ to determine if the difference in the potency of the drugs are statistically significant or not. A $p$ value $>0.05$ indicates no statistical differences while a $p$ value $<0.001$ indicated statistical significant differences. The statistical analysis data are not included in this report. 
Supplementary Materials: The NMR spectra $\left({ }^{1} \mathrm{H}-\mathrm{NMR},{ }^{13} \mathrm{C}-\mathrm{NMR}\right)$ of compounds $2-6$ are available online at http://www.mdpi.com/1420-3049/25/3/566/s1.

Author Contributions: Conceptualization M.O., F.S., G.A. Methodology M.O., P.S., F.S., G.A.; Formal analysis M.O., P.S., T.I., F.S., M.N., G.A.; Investigation, M.O., P.S., G.A.; Writing—original draft preparation, M.O., M.N., G.A.,T.I; Writing-review and editing, M.O., P.S., T.I., F.S., M.N., G.A.; Funding acquisition, F.S., M.N., G.A. Authorship must be limited to those who have contributed substantially to the work reported. All authors have read and agreed to the published version of the manuscript.

Funding: This study was supported by research grants from Cancer Care Manitoba to M.N./G.A. and Natural Sciences and Engineering Council of Canada (NSERC-DG-06047) grant to F.S. M.O. was the recipient of a University of Manitoba and Manitoba provincial government graduate fellowships (UMGF and MGS).

Conflicts of Interest: The authors declare no conflict of interest. The funders had no role in the design of the study; in the collection, analyses, or interpretation of data; in the writing of the manuscript, or in the decision to publish the results.

\section{References}

1. Fitzmaurice, C.; Akinyemiju, T.F.; Al Lami, F.H.; Alam, T.; Alizadeh-Navaei, R.; Allen, C.; Alsharif, U.; Alvis-Guzman, N.; Amini, E.; Anderson, B.O.; et al. Global, Regional, and National Cancer Incidence, Mortality, Years of Life Lost, Years Lived With Disability, and Disability-Adjusted Life-Years for 29 Cancer Groups, 1990 to 2016: A Systematic Analysis for the Global Burden of Disease Study. JAMA Oncol. 2018, 4, 1553-1568. [PubMed]

2. Arthur, G.; Bittman, R. Glycosylated antitumor ether lipids: Activity and mechanism of action. Anticancer Agents Med. Chem. 2014, 14, 592-606. [CrossRef] [PubMed]

3. Arthur, G.; Schweizer, F.; Ogunsina, M. Synthetic glycosylated ether glycerolipids as anticancer agents. In Carbohydrates in Drug Design and Discovery; Jiménez-Barbero, J., Cañada, F.J., Martin-Santamaria, S., Eds.; Royal Society of Chemistry: Cambridge, UK, 2015.

4. Idowu, T.; Samadder, P.; Arthur, G.; Schweizer, F. Amphiphilic Modulation of Glycosylated Antitumor Ether Lipids Results in a Potent Triamino Scaffold against Epithelial Cancer Cell Lines and BT474 Cancer Stem Cells. J. Med. Chem. 2017, 60, 9724-9738. [CrossRef] [PubMed]

5. Moraya, A.I.; Ali, J.L.; Samadder, P.; Liang, L.; Morrison, L.C.; Werbowetski-Ogilvie, T.E.; Ogunsina, M.; Schweizer, F.; Arthur, G.; Nachtigal, M.W. Novel glycolipid agents for killing cisplatin-resistant human epithelial ovarian cancer cells. J. Exp. Clin. Cancer Res. 2017, 36, 67. [CrossRef] [PubMed]

6. Ogunsina, M.; Samadder, P.; Idowu, T.; Arthur, G.; Schweizer, F. Design, synthesis and evaluation of cytotoxic properties of bisamino glucosylated antitumor ether lipids against cancer cells and cancer stem cells. MedChemComm 2016, 7, 2100-2110. [CrossRef]

7. Ogunsina, M.; Samadder, P.; Idowu, T.; Arthur, G.; Schweizer, F. Replacing d-Glucosamine with Its 1-Enantiomer in Glycosylated Antitumor Ether Lipids (GAELs) Retains Cytotoxic Effects against Epithelial Cancer Cells and Cancer Stem Cells. J. Med. Chem. 2017, 60, 2142-2147. [CrossRef] [PubMed]

8. Samadder, P.; Bittman, R.; Byun, H.S.; Arthur, G. A glycosylated antitumor ether lipid kills cells via paraptosis-like cell death. Biochem. Cell Biol. 2009, 87, 401-414. [CrossRef] [PubMed]

9. Samadder, P.; Byun, H.S.; Bittman, R.; Arthur, G. An active endocytosis pathway is required for the cytotoxic effects of glycosylated antitumor ether lipids. Anticancer Res. 2011, 31, 3809-3818. [PubMed]

10. Samadder, P.; Xu, Y.; Schweizer, F.; Arthur, G. Cytotoxic properties of D-gluco-, D-galacto- and D-manno-configured 2-amino-2-deoxy-glycerolipids against epithelial cancer cell lines and BT-474 breast cancer stem cells. Eur. J. Med. Chem. 2014, 78, 225-235. [CrossRef] [PubMed]

11. Maltese, W.A.; Overmeyer, J.H. Methuosis: Nonapoptotic cell death associated with vacuolization of macropinosome and endosome compartments. Am. J. Pathol. 2014, 184, 1630-1642. [CrossRef] [PubMed]

12. Keoni, C.L.; Brown, T.L. Inhibition of Apoptosis and Efficacy of Pan Caspase Inhibitor, Q-VD-OPh, in Models of Human Disease. J. Cell Death 2015, 8, JCD-S23844. [CrossRef] [PubMed]

13. Kramer, S.D. Wunderli-Allenspach H: No entry for TAT(44-57) into liposomes and intact MDCK cells: Novel approach to study membrane permeation of cell-penetrating peptides. Biochim. Biophys. Acta 2003, 1609, 161-169. [CrossRef]

14. Markovits, J.; Roques, B.P.; Le Pecq, J.B. Ethidium dimer: A new reagent for the fluorimetric determination of nucleic acids. Anal. Biochem. 1979, 94, 259-264. [CrossRef] 
15. Dai, Y.; Lawrence, T.S.; Xu, L. Overcoming cancer therapy resistance by targeting inhibitors of apoptosis proteins and nuclear factor-kappa B. Am. J. Transl. Res. 2009, 1, 1-15. [PubMed]

16. Deming, P.B.; Schafer, Z.T.; Tashker, J.S.; Potts, M.B.; Deshmukh, M.; Kornbluth, S. Bcr-Abl-mediated protection from apoptosis downstream of mitochondrial cytochrome c release. Mol. Cell Biol. 2004, 24, 10289-10299. [CrossRef] [PubMed]

17. Fulda, S. Tumor resistance to apoptosis. Int. J. Cancer 2009, 124, 511-515. [CrossRef] [PubMed]

Sample Availability: Samples of the compound 3 are available from the authors.

(C) 2020 by the authors. Licensee MDPI, Basel, Switzerland. This article is an open access article distributed under the terms and conditions of the Creative Commons Attribution (CC BY) license (http://creativecommons.org/licenses/by/4.0/). 